\title{
Emx1-Lineage Progenitors Differentially Contribute to Neural Diversity in the Striatum and Amygdala
}

\author{
Laura A. Cocas, ${ }^{1,2}$ Goichi Miyoshi, ${ }^{3 \star}$ Rosalind S. E. Carney, ${ }^{1 \star}$ Vitor H. Sousa, ${ }^{3}$ Tsutomu Hirata, ${ }^{1}$ Kevin R. Jones, ${ }^{4}$ \\ Gord Fishell, ${ }^{3}$ Molly M. Huntsman, ${ }^{1,2}$ and Joshua G. Corbin ${ }^{1}$ \\ ${ }^{1}$ Center for Neuroscience Research, Children's Research Institute, Children's National Medical Center, Washington, DC 20010, ${ }^{2}$ Interdisciplinary Program \\ in Neuroscience, Georgetown University Medical Center, Washington, DC 20057, ${ }^{3}$ Neuroscience Program and Department of Cell Biology, Smilow Research \\ Center, New York University School of Medicine, New York, New York 10016, and ${ }^{4}$ Department of Molecular, Cellular, and Developmental Neurobiology, \\ University of Colorado, Boulder, Colorado 80309
}

In the developing mammalian basal telencephalon, neural progenitors from the subpallium generate the majority of inhibitory medium spiny neurons (MSNs) in the striatum, while both pallial- and subpallial-derived progenitors contribute to excitatory and inhibitory neuronal diversity in the amygdala. Using a combination of approaches, including genetic fate mapping, cell birth dating, cell migration assays, and electrophysiology, we find that cells derived from the Emxl lineage contribute to two distinct neuronal populations in the mature basal forebrain: inhibitory MSNs in the striatum and functionally distinct subclasses of excitatory neurons in the amygdala. Our cell birth-dating studies reveal that these two populations are born at different times during early neurogenesis, with the amygdala population born before the MSNs. In the striatum, Emx1-lineage neurons represent a unique subpopulation of MSNs: they are disproportionately localized to the dorsal striatum, are found in dopamine receiving, reelin-positive patches, and are born throughout striatal neurogenesis. In addition, our data suggest that a subpopulation of these Emx1-lineage cells originate in the pallium and subsequently migrate to the developing striatum and amygdala. Our intersectional fate-mapping analysis further reveals that Emxl-lineage cells that coexpress Dlx exclusively generate MSNs but do not contribute to the excitatory neurons in the amygdala. Thus, both the timing of neurogenesis and differential combinatorial gene expression appear to be key determinants of striatal versus amygdala fate decisions of Emx1-lineage cells.

\section{Introduction}

Neuronal diversity in the mature telencephalon is generated during embryogenesis, in which progenitor pools are formed from the regional gene expression of key transcription factors. Multiple ventral telencephalic (subpallial) progenitor pools contribute

\footnotetext{
Received May 31, 2009; revised 0ct. 22, 2009; accepted 0ct. 31, 2009.

This work was supported by the following grants: National Institute on Drug Abuse Grant R01 NIDA020140 (J.G.C.), National Research Service Award Fellowship NS564662 (L.A.C.), and Cellular Imaging Core of Mental Retardation and Developmental Disabilities Research Center Grant P30HD40677. We thank the following people for sharing of reagents: K. Campbell for the Gsx2 antibody, R. Hevner for the Tbr1 antibody, K. Yoshikawa for the Dlx2 antibody, M. Baydyuk for the TH antibody, Elizabeth Powell for the MOR1- $\beta$ antibody, and T. Haydar for the CAG-RFP construct. We thankJ.-M. Mangin for assistance with confocal microscopy and electrophysiological data analysis and preparation and M. R. Costa for advice regarding the in vitro differentiation assay. We also thank the following people for their critical comments and reading of this manuscript: V. Gallo, T. Haydar, and J. L. Olmos-Serrano. L.A.C. and J.G.C. designed and planned the experiments and wrote this manuscript. L.A.C. performed all of the experiments with the exception of the electrophysiology, which was done with M.M.H. L.A.C. also performed all of the data analysis and figure preparation. G.M. generated the DIx-Flpe mouse and provided relevant crosses in the laboratory of G.F. R.S.E.C. performed a subset of BrdU injections and perfusions and provided technical assistance and intellectual input. V.H.S. generated the RCE: dual reporter mice. T.H. conducted preliminary analysis of early Emx1 expression and recombination. K.R.J. provided Emx1-Cre mice.

${ }^{*}$ G.M. and R.S.E.C. contributed equally to this work.

Correspondence should be addressed to Joshua G. Corbin, Center for Neuroscience Research, Children's Research Institute, Children's National Medical Center, 111 Michigan Avenue NW, Washington, DC 20010. E-mail: jcorbin@cnmcresearch.org.

R. S. E. Carney's present address: Molecular Neurobiology Laboratory, The Salk Institute, 10010 North Torrey Pines Road, La Jolla, CA 92037.

D01:10.1523/JNEUROSCI.2525-09.2009

Copyright $\odot 2009$ Society for Neuroscience $\quad$ 0270-6474/09/2915933-14\$15.00/0
}

to the developing striatum, the inhibitory center of the telencephalon vital for movement and impulse control (Wichterle et al., 1999, 2001; Marin et al., 2000; Nery et al., 2002). The majority (90-95\%) of the striatum is composed of GABAergic medium spiny neurons (MSNs) (Gerfen, 1992), which are derived primarily from the lateral ganglionic eminence (LGE) (Wichterle et al., 1999, 2001). These cells migrate radially and separate into two primary striatal compartments: the patches, which are formed from MSN precursors, the majority of which are born early [in the mouse between embryonic day 12.5 (E12.5) and E13.5]; and the surrounding matrix, the majority of which are born later (E13.5-E15.5) (Fishell and van der Kooy, 1987, 1991; Gerfen, 1992; Krushel et al., 1993; Mason et al., 2005).

Another major basal telencephalic structure is the amygdala, a key component of the limbic system. The amygdala plays an important role in modulating fear, aggression, and emotionality (Swanson and Petrovich, 1998; Sah et al., 2003; Maren and Quirk, 2004). Similar to the striatum, multiple progenitor pools contribute to the amygdala, and several lines of evidence indicate that this structure is derived from dorsal (pallial) and ventral (subpallial) progenitors, at least some of which are born early in embryonic neurogenesis (Nery et al., 2002; Carney et al., 2006; Remedios et al., 2007; Bai et al., 2008; Hirata et al., 2009; Soma et al., 2009).

Previous work has revealed that progenitor populations marked by the pallial-expressed transcription factor, Emx1, ap- 
pear to contribute to numerous telencephalic structures, including the striatum (Willaime-Morawek et al., 2006; WillaimeMorawek and van der Kooy, 2008), olfactory bulb (Fogarty et al., 2007; Kohwi et al., 2007; Young et al., 2007), and amygdala (Puelles et al., 2000; Gorski et al., 2002; Medina et al., 2004; Tole et al., 2005). However, the relationship between the origin and timing of the generation of $E m \times 1^{+}$progenitors and their ultimate fate in the mature striatum and amygdala remains unknown.

In this study, we used a multidisciplinary approach to investigate key developmental aspects of the striatum and amygdala, including the genetic heterogeneity and origin of the Emx1 lineage, the timing of their genesis, and their ultimate fate in these two structures. Our data reveal a relationship between the timing of the generation and the postnatal fate of Emx1-lineage progenitors in the striatum and amygdala. By use of an intersectional genetic fate-mapping strategy, our data also reveal that, in addition to timing, differential combinatorial gene expression within Emx1-lineage cells may be an important determinant of their distinct fates in the striatum versus the amygdala. These findings provide novel insight into the plasticity of a subset of telencephalic neural progenitors from a broadly common lineage, wherein their ultimate neuronal fate in the postnatal brain appears to be related to both the timing of their birth and combinatorial gene expression during embryogenesis.

\section{Materials and Methods}

Animal use. Swiss Webster (Taconic Farms), Z/EG, ROSA-YFP, ROSALacZ (Jackson Laboratory) (Novak et al., 2000; Srinivas et al., 2001), Emx1-Cre (K. Jones, University of Colorado, Boulder, CO) (Gorski et al., 2002), and Small eye (Sey) (Hill et al., 1991) mice used in these studies were maintained according to the protocols approved by Children's $\mathrm{Na}$ tional Medical Center and Georgetown University Medical Center. Emx1-Cre, ROSA-YFP, and Sey ${ }^{+-}$; Emx1-Cre mice were maintained on a mixed $\mathrm{C} 57 \mathrm{BL} / 6 \times \mathrm{SW}$ background; $Z / E G$ mice were maintained on an SW background. For the intersectional fate-mapping studies (see Fig. 7) Emx1-Cre, Dlx5/6-Flpe, and RCE: dual mice were maintained according to the protocols approved by the New York University School of Medicine, NY. For these experiments, the neo cassette from Emx1-Cre driver mice (T. Iwasato, BSI RIKEN, Japan) was removed before crossing. Dlx5/ 6-Flpe driver mice (G. Miyoshi and G. Fishell, unpublished observations) expressed the Flpe site-specific recombinase under control of the intergenic enhancer residing between Dlx5 and Dlx6 (Stenman et al., 2003). To generate $R C E$ : dual reporter mice, a CAG promoter with floxed and flrted stop cassettes followed by EGFP reporter was targeted to the R26R locus (Sousa et al., 2009). For staging of the embryos, midday of vaginal plug detection was considered as E0.5. For postnatal animals, the day of birth was considered as postnatal day 0 (P0). The genotyping of animals was performed as described previously (Gorski et al., 2002; Carney et al., 2009).

Tissue preparation and histology. For immunofluorescence and in situ hybridization at embryonic ages, brains were fixed in $4 \%$ paraformaldehyde (PFA) for $2 \mathrm{~h}$ and overnight, respectively. Brains were cryoprotected by sucrose immersion, embedded in Histoprep (Fisher Scientific), and frozen. Serial coronal sections of embedded tissue were cut at 20-30 $\mu \mathrm{m}$ thickness using a cryostat and mounted on glass slides.

Immunohistochemistry. Cryostat mounted sections were air dried and rinsed three times in PBS before blocking for $1 \mathrm{~h}$ in $10 \%$ normal donkey serum diluted in PBS with $0.2 \%$ Triton to prevent nonspecific binding. Primary antibodies were diluted in $1 \%$ serum diluted in PBS with $0.2 \%$ Triton; sections were incubated in primary antibody overnight at $4^{\circ} \mathrm{C}$. The primary antibodies used were as follows: goat anti-Pax6 (1:200), mouse anti-NeuN (1:500; Covance), rabbit anti-Ng2 (1:400, Covance), mouse anti-GFAP (1:200, Sigma), rabbit anti-DARPP-32 (1:1000, Covance), rat anti-BrdU (1:250, Serotec), mouse BrdU (1:50, Sigma), rat anti-GFP (Nacala, 1:2000), rabbit anti-Gsx2 (1:1500, gift from K. Campbell, Cincinnati Children's Hospital, Cincinnati, OH), mouse anti-CC1
(1:50, Calbiochem), rabbit anti-Tbr1 (1:1000; gift from R. Hevner, University of Washington, Seattle, WA), guinea pig anti-Dlx2 (1:1500; gift from K. Yoshikawa, Osaka University, Osaka, Japan), rat anti-CTIP2 (1.300; Abcam), rabbit anti-tyrosine hydroxylase (anti-TH) (1:1000; Millipore Bioscience Research Reagents), mouse anti-reelin (1:1000, Millipore Bioscience Research Reagents), rabbit anti- $\mu$-opioid receptor- $\beta$ (anti-MOR1- $\beta$ ) (1:10,000; Millipore), and rat antisomatostatin (ant-SST) (1:1000; Millipore). To detect primary antibodies, secondary antibodies raised in mouse, rat, goat, guinea pig, and rabbit were used (Cy3 and Cy5 at 1:200, FITC at 1:50; all from Jackson Immunoresearch). Sections were incubated for $2 \mathrm{~h}$ in $1 \%$ serum in PBS with $0.2 \%$ Triton and were washed and coverslipped with gel mount (Sigma) or Vectashield with DAPI (Vector Labs). Sections coverslipped with gel mount were incubated first with To-Pro-3 iodide (1:100, Invitrogen) for $10 \mathrm{~min}$ and then washed and coverslipped.

BrdU labeling. To label cells in S phase, E9.5, E11.5, E13.5, E14.5, and E15.5 Emx1-Cre; ROSA-YFP pregnant dams were administered BrdU (Sigma), which was dissolved in PBS, by intraperitoneal injection at a dose of $100 \mathrm{mg} / \mathrm{kg}$. To achieve short-term labeling, the dams were killed after $2 \mathrm{~h}$ and embryos were prepared for processing as described above. Cryostat sections were processed for immunohistochemical labeling of YFP using rat anti-GFP, as described above, and postfixed with $4 \%$ PFA for $15 \mathrm{~min}$. A sodium citrate pretreatment was performed before processing sections for BrdU immunohistochemistry, as described previously (Tang et al., 2007). Briefly, a food steamer (Oster 6.1 quart model) was preheated to $100^{\circ} \mathrm{C}$, and slides were placed horizontally in the incubator, covered with $500 \mu \mathrm{l}$ of $10 \mathrm{~mm}$ sodium citrate, and incubated for $15 \mathrm{~min}$. Slides were allowed to cool for 2 min before standard immunohistochemistry procedures were continued.

In situ hybridization. Tissue was prepared as described above. Nonradioactive-dioxygenin-labeled RNA in situ hybridization was performed as described previously (Carney et al., 2009). The probes used in this study were Emxl (Yoshida et al., 1997) and Cre (Hirata et al., 2009).

DiI cell migration assay. E11.5 and E13.5 brains were dissected in icecold HBSS (Invitrogen), the skull and meninges were removed, and brains were placed in 3\% low-melting-point agarose (Fisher Scientific). Slices $(250-300 \mu \mathrm{m})$ were cut using a vibratome (VT1000S; Leica), and sections were allowed to recover at $37^{\circ} \mathrm{C}$ in MEM supplemented with L-glutamine (1:100), penicillin/streptomycin (1:100), and 10\% fetal bovine serum (all from Invitrogen). DiI crystals were placed in the lateral pallium and the slices were cultured in neurobasal medium supplemented with L-glutamine (1:100), penicillin/streptomycin (1: $100)$, and B-27 (1:50; Invitrogen) for $2 \mathrm{~d}$ in vitro (DIV). After culture, sections were washed in PBS, postfixed in 4\% PFA for $15 \mathrm{~min}$, and washed again in PBS. Sections were then coverslipped using concave slides (Fisher Scientific), and slices in which DiI was targeted to the ventral or lateral pallium and $\mathrm{DiI}^{+}$cells were observed migrating ventrally were immediately photographed.

In utero electroporation. Electroporations were performed as previously described (Gal et al., 2006). CAG-RFP was used at a concentration of $4 \mu \mathrm{g} / \mu \mathrm{l}$, diluted in PBS and Fast-Green. RFP $(1 \mu \mathrm{l})$ was injected into the lateral ventricles of E12.5-E14.5 embryo brains, and micro tweezertrodes were oriented with the positive electrode over the cortical primordium; four pulses of $33 \mathrm{mV}$ of current were then applied, with $50 \mathrm{~ms}$ intervals. Embryos were then allowed to survive for $1 \mathrm{~d}$, for $3 \mathrm{~d}$, or to full term, and they were killed postnatally at P15 or P30. Brains were processed as in preparation for immunohistochemistry. The location of electroporation was determined by examining the brain in serial coronal sections. Only animals with $\mathrm{RFP}^{+}$electroporated cells in the pallium or cortex were analyzed.

Electrophysiology. Electrophysiological recordings were performed from fluorescent Emx1-lineage cells located in the striatum and basolateral nucleus of the amygdala. Briefly, animals were deeply anesthetized (with $\mathrm{CO}_{2}$ ) until nonresponsive and then decapitated. Brains were removed and immediately immersed for 2-3 $\mathrm{min}$ in an ice-cold oxygenated $\left(95 \% \mathrm{O}_{2} / 5 \% \mathrm{CO}_{2}\right)$ sucrose slicing solution containing the following (in mm): 234 sucrose, 11 glucose, $24 \mathrm{NaHCO}_{3}, 2.5 \mathrm{KCl}, 1.25 \mathrm{NaH}_{2} \mathrm{PO}_{4}$. $\mathrm{H}_{2} \mathrm{O}, 10 \mathrm{MgSO}_{4}$, and $0.5 \mathrm{CaCl}_{2}$. Coronal slices containing the striatum or amygdala were cut on a vibratome (Leica) at $250 \mu \mathrm{m}$. Slices were collected 
and placed in an oxygenated incubation chamber containing preheated $\left(32^{\circ} \mathrm{C}\right)$ oxygen-equilibrated artificial cerebral spinal fluid (ACSF) containing the following (in mM): $126 \mathrm{NaCl}, 26 \mathrm{NaHCO}_{3}, 10$ glucose, $2.5 \mathrm{KCl}, 1.25$ $\mathrm{NaH}_{2} \mathrm{PO}_{4} \cdot \mathrm{H}_{2} \mathrm{O}, 2 \mathrm{MgCl}_{2} \cdot 6 \mathrm{H}_{2} \mathrm{O}$, and $2 \mathrm{CaCl}_{2} \cdot 2 \mathrm{H}_{2} \mathrm{O} ; \mathrm{pH}$ 7.4. The slices were incubated for $1 \mathrm{~h}$ at $32^{\circ} \mathrm{C}$ and then allowed to cool to room temperature until being transferred to the recording chamber. Neurons were located and visualized with a fixed-stage upright microscope (E600 FN Nikon) equipped with a $4 \times$ objective and a $60 \times$ insulated objective, infrared (IR) illumination, Nomarski optics, an IR-sensitive video camera (Cohu), and fluorescent lamp (D-FI universal epi-fluor illuminator, Nikon) equipped with a $450-490 \lambda$ filter. Glass pipettes (nonfilament borosilicate glass, Garner Glass) were pulled with a Flaming/Brown micropipette puller (model P-97, Sutter Instruments) to a resistance of 3-5 $\mathrm{M} \Omega$. For all recordings the intracellular pipette solution consisted of the following (in mM): $130 \mathrm{~K}$-gluconate, $10 \mathrm{KCl}, 10 \mathrm{HEPES}, 10 \mathrm{EGTA}$, and $2 \mathrm{MgCl}_{2}$. Recordings were performed at room temperature with continuous perfusion $(2 \mathrm{ml} / \mathrm{min})$ of ACSF. Cells were recorded in current-clamp mode using a multiclamp 700A amplifier (Axon) and digitizer (DigiDATA, Axon). For all cells, membrane potential and input resistance values were recorded. For all current-clamp recordings, current was injected into the cell to keep the cell at $-60 \mathrm{mV}$. Cells were then characterized on the response to depolarizing and hyperpolarizing current pulses for a duration of $600 \mathrm{~ms}$ in 12 consecutive sweeps. For striatal cells, threshold responses were measured and rheobase currents were recorded. Cells were analyzed off-line using pClamp software (Axon) and specialized graphing software (Origin).

In vitro differentiation assay. E13.5 Emx1-Cre; ROSA-YFP brains were dissected out in ice-cold HBSS and divided into medial pallium, dorsal pallium, ventral/lateral pallium, and LGE regions. Cells were disassociated and plated in MEM with supplements on PDL-coated coverslips, as described in detail previously (Costa et al., 2008). After 1 DIV, $100 \mu \mathrm{l}$ of B27 was added to the medium. Cells were cultured for $10 \mathrm{~d}$, fixed, immunostained with antibodies to GAD65/67 and CTIP2, and subsequently counterstained with DAPI.

Microscopy. In situ hybridization photographs were taken using an Olympus BX51 microscope. Fluorescent photographs were taken using a Zeiss LSM 510 confocal microscope. For confocal image analysis, each fluorophore was scanned sequentially and $z$-stacks of the images obtained were collapsed into a single projection image or presented as individual optical sections. Figures were prepared using ImageJ (NIH) and Adobe Illustrator; brightness and contrast adjustments were applied equally across all images.

Data analysis. Postnatal sections from Emx1-cre; ROSA-YFP brains were photographed as described above. For each immunohistochemical marker, three coronal sections of dorsal striatum at bregma levels $0.14-$ 0.98 were examined from $n=3$ animals, except where noted. The following criteria were applied to determine colocalization of cell subtype markers with YFP fluorescence. (1) Cells were counted from individual optical sections, not collapsed projection images. (2) Cells were counted as double positive if an immunopositive YFP cell body was clearly colocalized with the fluorophore of interest and contained a nucleus that was also DAPI positive. (3) For BrdU quantification, cells were counted as $\mathrm{BrdU}^{+}$if they contained medium to strong labeling with BrdU, defined as labeling at least $50 \%$ of the DAPI nuclear stain. Percentages of Emx1lineage and Emx1-negative MSNs (see Fig. 3) were calculated by dividing the total number of $\mathrm{BrdU}^{+} \mathrm{YFP}^{+}\left(\right.$or YFP $\left.^{-}\right)$DARPP- $32^{+}$cells by the number of $\mathrm{YFP}^{+}\left(\right.$or $\left.\mathrm{YFP}^{-}\right)$DARPP- $32^{+}$cells for each age. For the amygdala, percentages of Emxl-lineage excitatory cells (see Fig. 3) were calculated by dividing the total number of $\mathrm{BrdU}^{+} \mathrm{YFP}^{+} \mathrm{Tbr}^{+}$cells by the number of $\mathrm{YFP}^{+} \mathrm{Tbrl}^{+}$cells for each age.

\section{Results}

\section{Fate of Emx1-lineage cells in the postnatal striatum and amygdala}

To determine the fate of Emx1-lineage cells in the postnatal striatum and amygdala, we crossed previously generated Emx1-Cre mice (Gorski et al., 2002) to ROSA-YFP reporter mice. We observed that $\mathrm{YFP}^{+}$Emx1-lineage cells were distributed preferen- tially in the dorsal striatum (Fig. $1 A$ ), a region that receives layer $\mathrm{V}$ cortical inputs, primarily from neocortical areas. To determine the cellular fate of Emx1-lineage cells in the striatum, we performed immunohistochemical analyses with antibodies to YFP and all mature striatal cell types, including inhibitory neuronal populations and glia. Additionally, we labeled with markers for the patch and matrix domains of the striatum. When labeling was done with neuronal markers, we found that $44 \%(89 / 198, n=3)$ of the Emx1-lineage cells in the striatum colocalized with NeuN, and that most $(96 \%, 67 / 70 n=2) \mathrm{YFP}^{+} / \mathrm{NeuN}^{+}$cells also coexpressed DARPP-32 (Fig. $1 B$ ). $\mathrm{YFP}^{+} / \mathrm{DARPP}-32^{+}$cells in the dorsal striatum revealed represented $\sim 4 \%(105 / 2713, n=3)$ of the total DARPP- $32{ }^{+}$MSN population. These Emx1-lineage cells also colabeled with CTIP2 (Fig. 1C), which, along with DARPP32, labels MSNs (Gerfen, 1992; Arlotta et al., 2008). In contrast, immunolabeling with several markers for interneuronal subtypes [parvalbumin, calretinin (CR), SST, neuropeptide Y, and neuronal nitric oxide synthase] revealed that approximately only one $\mathrm{YFP}^{+}$cell per section also expressed CR, with no $\mathrm{YFP}^{+}$cells colocalizing with other markers of inhibitory neurons (data not shown). In addition, we found that many Emx1-lineage cells expressed CC1 $(26 \%, 49 / 188, n=3)$, GFAP $(9 \%, 17 / 179, n=3)$, or NG2 $(21 \%, 43 / 240, n=3)$, markers for mature oligodendrocytes, astrocytes, or glial progenitors, respectively (supplemental Fig. 1, available at www.jneurosci. org as supplemental material; Table 1).

As the largest population of striatal neurons derived from the Emx1 lineage were DARPP- $32^{+} / \mathrm{CTIP}^{+}{ }^{+} \mathrm{MSN}$, we wanted to determine whether these neurons contributed to both major subdivisions of the striatum, patch (also called striosomes) and matrix. We labeled the patch domains with reelin and MOR $1-\beta$, and the matrix domains with SST and CB, as SST ${ }^{+}$fibers from the cortex allow demarcation of the matrix and $\mathrm{CB}$ labels projection neurons in the matrix (Gerfen, 1985, 1992; Alcántara et al., 1998; Arlotta et al., 2008). Few Emx1-lineage MSNs were found in the $\mathrm{SST}^{+}$fiber-rich matrix, and a small number of Emx1-lineage colocalized with $\mathrm{CB}$ (Fig. 1D,E). In contrast, we found that the majority (91\%, 98/108, $n=2)$ of Emx1-lineage MSNs were in reelin-positive patches, while only $44 \%(1153 / 2630, n=2)$ of YFP-negative MSNs were present in reelin-positive patches (Fig. $1 F)$. This result was further supported by the colocalization of $\mathrm{YFP}^{+}$cells with MOR1- $\beta$ expression (Fig. $1 G$ ). In addition, we found that $100 \%(28 / 28, n=2)$ of Emxl-lineage MSNs were in $\mathrm{TH}^{+}$domains (Fig. $1 \mathrm{H}$ ). TH labeling marks dopaminergic projections from the substantia nigra, also referred to as dopaminergic islands. Thus, Emxl-lineage progenitors gave rise to patch MSNs innervated by dopaminergic inputs from the substantia nigra.

In addition to patch/matrix subdivisions, striatal MSNs can also be classified based on their output projections. MSNs receive excitatory projections primarily from layer $\mathrm{V}$ of the cortex, and send inhibitory projections out of the striatum through two primary pathways (Gerfen, 1985). Direct pathway MSNs project directly to the substantia nigra, express $D_{1}$ dopamine receptors ( $\mathrm{D}_{1}$ nigral MSNs of the direct pathway), and facilitate movement (Gerfen et al., 1990). Indirect pathway MSNs project to the substantia nigra via the globus pallidus, and express $\mathrm{D}_{2}$ dopamine receptors $\left(\mathrm{D}_{2}\right.$ pallidal MSNs of the indirect pathway), and inhibit movement. To determine whether Emx1-lineage MSNs were part of one or both of these circuits, we performed whole-cell currentclamp recordings using previously established physiological criteria to differentiate between $\mathrm{D}_{1}$ and $\mathrm{D}_{2}$ MSN subtypes (Ade et al., 2008; Gerfen et al., 2008). Based on the spiking threshold of 

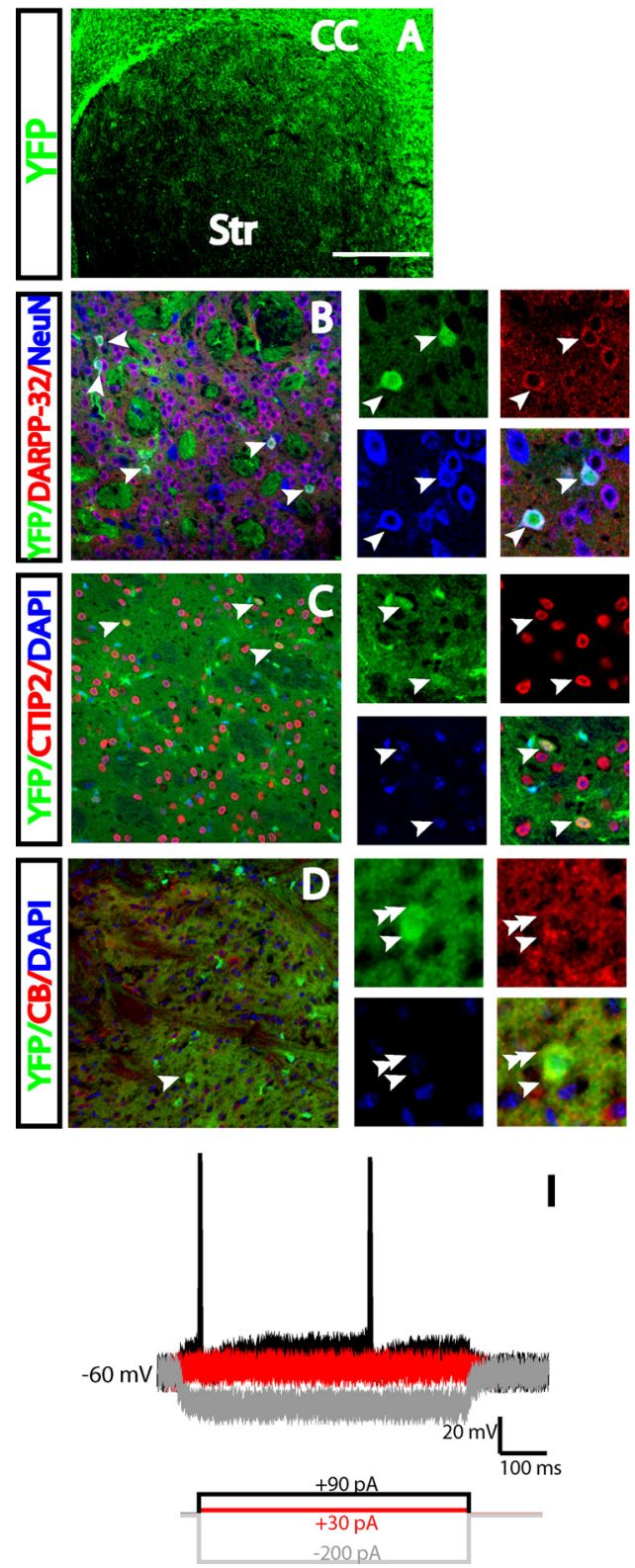
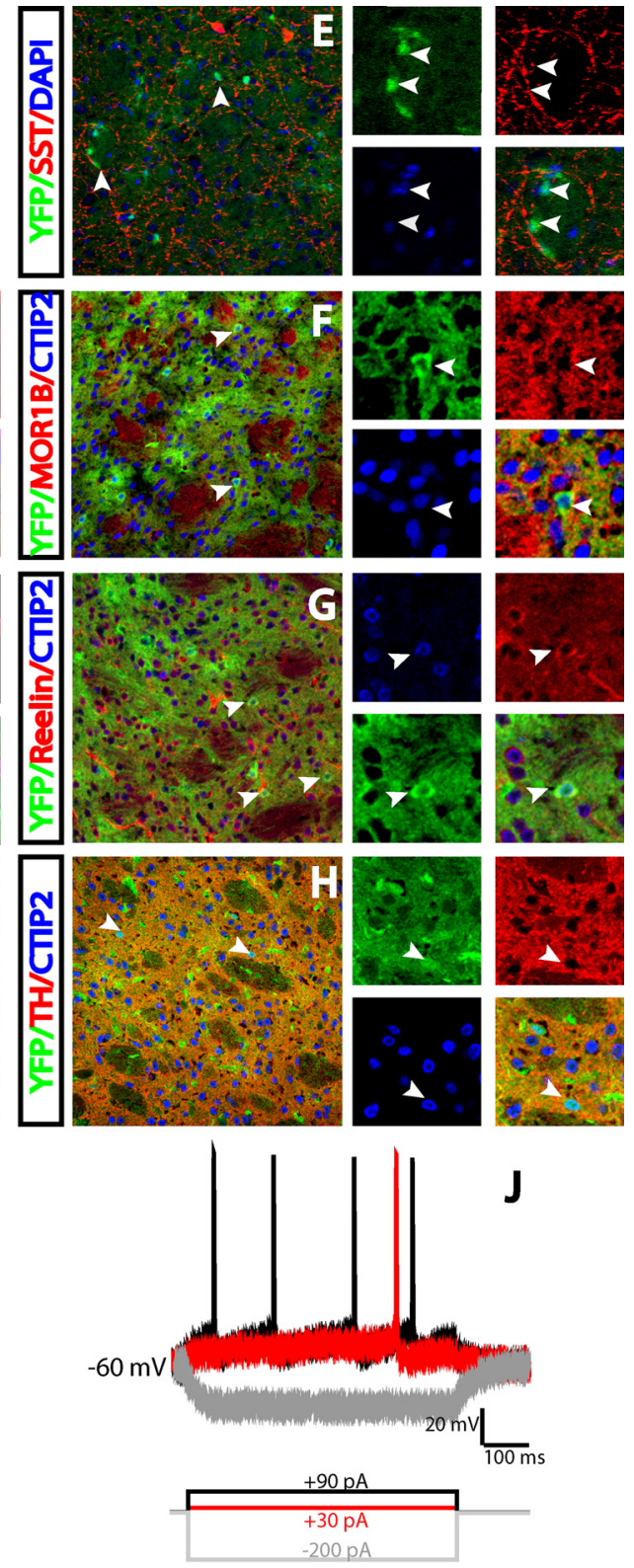

Figure 1. Emx1-lineage cells give rise to patch MSNs in the mature striatum. A, Low-power image of P30 Emx1-Cre; ROSA-YFP striatum shows YFP ${ }^{+}$Emx 1 -lineage cells present at high levels in the dorsal striatum. In this panel, lateral is to the right and medial is to the left. $B, C$, Higher magnification of a single confocal optical section of the mediodorsal striatum shows triple labeled $\mathrm{YFP}^{+} / \mathrm{DARPP}-32^{+} / \mathrm{NeuN}^{+}$neurons ( $\boldsymbol{B}$, arrowheads). YFP ${ }^{+}$cells are also labeled by the MSN marker CTIP2 ( $\boldsymbol{C}$, arrowheads). $\boldsymbol{D}$, Few Emx1-lineage neurons are labeled by the matrix projection neuron marker calbindin (arrowheads point to a positive cell, double arrowheads point to a negative cell). $E$, YFP ${ }^{+}$cells are found outside of the domain of SST ${ }^{+}$fibers, which demarcates the matrix (arrowheads). $\boldsymbol{F}-\boldsymbol{H}$, Immunolabeling with patch markers $\mu$-opioid receptor-1 $\beta$ (F, arrowheads) and reelin ( $G$, arrowheads) reveals colocalization with YFP ${ }^{+}$Emx 7 -lineage neurons. YFP ${ }^{+}$cells are also surrounded by $\mathrm{TH}^{+}$fibers $\left(\boldsymbol{H}\right.$, arrowheads). $\boldsymbol{I}, \boldsymbol{J}$, Patch-clamp recordings of YFP ${ }^{+}$cells in the striatum reveal that Emx 1 -lineage neurons are both $\mathrm{D}_{1}$ - and $\mathrm{D}_{2}$-type $M S \mathrm{~S}_{\mathrm{N}}$. $\boldsymbol{I}$, Trace from a single $\mathrm{D}_{1}$-like YFP ${ }^{+}$cell; current held at $-60 \mathrm{mV}$. Average resting membrane potential was $-87.2 \mathrm{mV}(n=2)$. J, Trace from a single $\mathrm{D}_{2}$-like YFP ${ }^{+}$cell; current held at $-60 \mathrm{mV}$. Average resting membrane potential was $-85.4 \mathrm{mV}(n=6)$. CC, Corpus callosum, Str, striatum. Scale bars: (in $\boldsymbol{A}) \boldsymbol{A}, 500 \mu \mathrm{m} ; \boldsymbol{B}-\boldsymbol{H}, 100 \mu \mathrm{m}$.

$\mathrm{YFP}^{+}$cells, we found that Emx1-lineage neurons were both high threshold $\mathrm{D}_{1}$-like MSNs (Fig. 1 I) $(2 / 8$ cells, rheobase $=90-100$ pA) and low-threshold $\mathrm{D}_{2}$-like MSNs (Fig. $\left.1 J\right)$ (Table 1) (6/8 cells; rheobase $=15-30 \mathrm{pA})$. As $\mathrm{D}_{1}$ MSNs make up $35 \%$ of striatal neurons, and $\mathrm{D}_{2}$ MSNs account for $40 \%$ of striatal neurons (Gerfen, 1992), our findings suggest that Emx1-lineage neurons disproportionately contribute to the $\mathrm{D}_{2}$ MSN subtype, as $75 \%$ of Emx1-lineage cells were $\mathrm{D}_{2}$-like MSNs. Thus, collectively these data reveal that $E m \times 1$-lineage progenitors gave rise to MSNs that preferentially localized to the patch domains, which receive cortical input from deep layer $V$ neurons and subcortical input from ventral tier dopaminergic neurons from the substantia nigra.
Furthermore, we found that Emxl-lineage-derived MSNs provide output to the substantia nigra via both direct and indirect pathways, although more Emx1-lineage MSNs contributed to the $\mathrm{D}_{2}$ MSN subpopulation that is responsible for inhibition of movement.

In addition to contributing to the postnatal striatum, consistent with previous studies (Gorski et al., 2002; Medina et al., 2004), we observed that Emx1-lineage cells also contributed to the postnatal amygdala. However, in previous studies the cellular fate of Emx1-lineage cells was not determined. We therefore examined whether Emx1-lineage cells in the mature amygdala gave rise to excitatory neurons similar to their pallial counterparts in 
Table 1. Emx1-lineage cells contribute to multiple neural subtypes in the basal forebrain

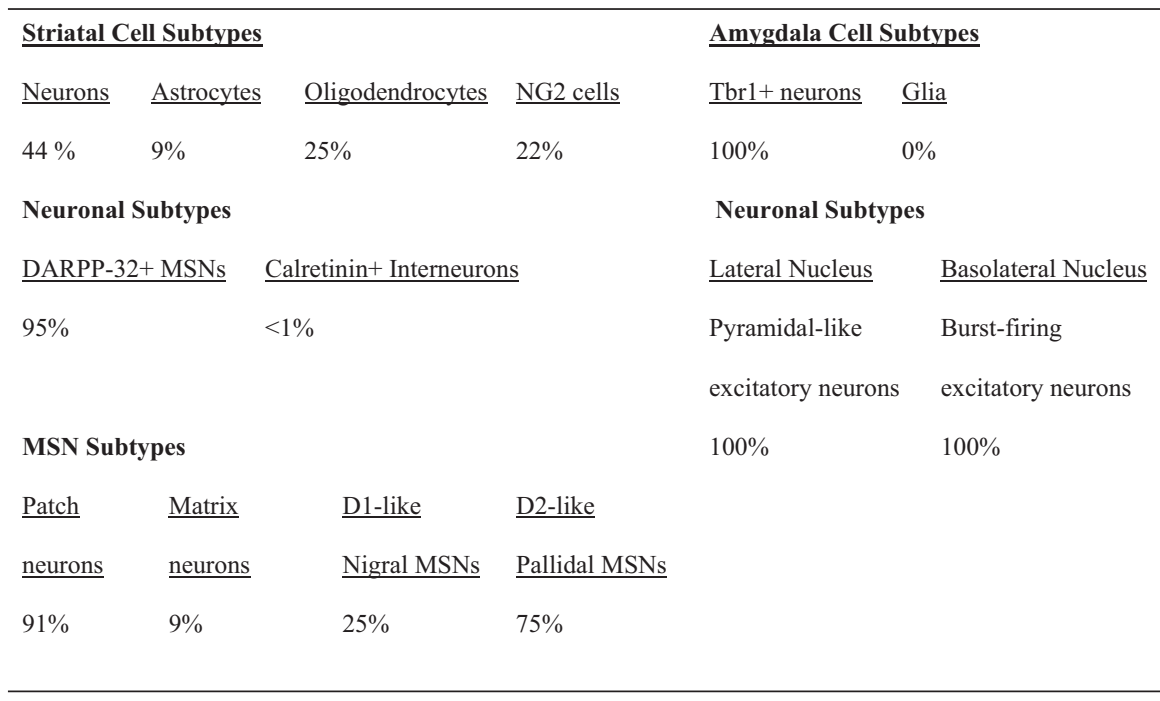

at all ages examined ( $3 \%$ at $\mathrm{E} 9.5, n=3$, $2 \%$ at $\mathrm{E} 11.5, n=2,3 \%$ at $\mathrm{E} 13.5, n=2,2 \%$ at E14.5, $n=3$, and $2 \%$ at E15.5, $n=2$ ).

We next examined whether Emx1lineage neurons in the amygdala are generated at different times than Emx1-lineage neurons in the striatum. Similar to the striatum, BrdU administration at E9.5 resulted in a small $(7 \%, 48 / 731, n=6)$ population of heavily labeled $\mathrm{BrdU}^{+} /$ Tbr1 ${ }^{+}$Emx1-lineage excitatory neurons in the lateral and basolateral amygdala (Fig. $3 E, F)$. In contrast, administration of BrdU 2 d later at E11.5 resulted in a larger population $(14 \%, 89 / 741, n=6)$ of strongly BrdU-labeled excitatory neurons of the Emxl lineage in both the postnatal lateral and basolateral amygdala, compared with the striatum. These cells were distributed throughout the lateral and basolateral nuclei (Fig. $\left.3 G^{\prime}, H\right)$. Additionally, also

the cerebral cortex, or to inhibitory neurons similar to their subpallial counterparts in the striatum. We found that, in contrast to the striatum, Emx1-lineage $\mathrm{YFP}^{+}$cells in the mature basolateral complex (BLC) of the amygdala colocalized exclusively with Tbr1 in the both the basolateral and lateral nuclei (Fig. $2 A-C$ ), with no $\mathrm{YFP}^{+}$cells expressing inhibitory neuronal markers. Previous studies (for review, see Sah et al., 2003) have revealed that, based on measures of firing properties, excitatory neurons in the lateral and basolateral amygdala comprise two distinct electrophysiological subtypes, pyramidal-like and burst-firing neurons. To examine the physiological fate of amygdala Emx1lineage cells, we performed patch-clamp slice recordings in the lateral and basolateral amygdala nuclei. This analysis revealed that Emx1-lineage cells generated these two cell types, which were interestingly segregated to separate nuclei. Emx1-lineage cells in the lateral nucleus exclusively gave rise to pyramidallike excitatory neurons $(n=7)$, whereas Emx1-lineage cells in the basolateral nucleus only gave rise to burst-firing excitatory neurons $(n=7)$ (Fig. $2 I-K$, Table 1$)$.

\section{Differences in the timing of the generation of striatal and amygdala $E m x 1$-lineage neurons}

As our above data revealed that the Emxl lineage generates different cell types in the striatum and the amygdala, we sought to determine whether developmental differences in timing of the birth of $E m \times 1^{+}$progenitors is related to the generation of these two disparate neuronal populations. To accomplish this, we used BrdU birth dating to label cells in S phase at E9.5, E11.5, E13.5, E14.5, and E15.5. In the striatum, a minority of Emx1-lineage MSNs were labeled with BrdU at early ages of BrdU administration [4\% $(4 / 103, n=3)$ at E9.5; $15 \%(9 / 59, n=2)$ at E11.5] (Fig. $3 A, D)$. BrdU administration at later ages resulted in more labeling of Emx1-lineage MSNs [23\% $(15 / 63, n=2)$ at E13.5, $29 \%$ $(21 / 78, n=3)$ at E14.5, and $27 \%(14 / 50, n=2)$ at E15.5] (Fig. $3 B-D)$. These birth dates were also coincident with the timing of neurogenesis of Emx1-negative MSNs, in which fewer Emx1negative MSNs are born early [3\% $(86 / 3339, n=3)$ at E9.5, and $11 \%(355 / 3221, n=2)$ at E11.5]. Birth dates of later born Emx1negative MSNs were also similarly distributed [33\% at E13.5 $(670 / 2032, n=2), 31 \%$ at E14.5 $(1272 / 4093, n=3)$, and $27 \%$ at E15.5 (703/2261, $n=2)$ ] (Fig. 3D). Emx1-lineage MSNs contributed between 2 and $3 \%$ of the total dividing MSN progenitor pool in contrast to the striatum, only very few $(2 \%, 9 / 555, n=3)$ amygdala neurons were heavily BrdU labeled when BrdU was administered at E13.5 (Fig. 3I,J). Interestingly, BrdU administration at this age selectively labeled intercalated cells, which are located at the boundary of the lateral and basolateral nuclei (Fig. 3I). These specialized inhibitory neurons regulate feedforward cortical inputs and fear circuitry outputs (Marowsky et al., 2005; Hefner et al., 2008; Likhtik et al., 2008). Very few neurons were born in the amygdala at later ages, with $1 \%$ labeled at E14.5 $(7 / 279, n=3)$, and at E15.5, with $0.1 \%$ labeled $(1 / 608, n=3)$ (data not shown). Therefore, Emx1-lineage cells that contribute to the amygdala precede the generation of Emx1-lineage cells that contribute to the striatum; these differences in timing are shown graphically in Figure $3 K$.

\section{Origins of basal telencephalic Emx1-lineage neurons}

Previous expression studies (Puelles et al., 2000; Gorski et al., 2002) revealed that Emxl is expressed throughout the lateral and dorsal pallial domains, beginning during early neurogenesis. This restricted expression pattern of Emxl raised the question as to whether striatal and amygdala Emx1-lineage cells were pallial derived. To test this we took a number of approaches. We first examined expression of Emxl during early neurogenesis, beginning at E9.5, when Emxl is first present, and compared this expression pattern to the pattern of Cre expression and the location of Emx1-lineage cells as revealed from Emx1-Cre; ROSA-LacZ crosses. We reasoned that recombined Emxl-lineage cells observed outside the domain of Emx1 and Cre expression most likely migrated from an $E m \times 1^{+}$source. Indeed, at E11.5 and E13.5, $\beta$-gal staining in Emx1-Cre; ROSA-LacZ brains revealed that Emx1-lineage cells were present in the ventral pallium (VP) and dorsal lateral ganglionic eminence (dLGE), beyond the domain of Emxl and Cre mRNA expression (supplemental Fig. $2 C, D, G, H, K, L$, available at www.jneurosci.org as supplemental material). This result suggested that $E m \times 1^{+}$cells had migrated from the pallium to the subpallium during early neurogenesis. In fact, late in embryogenesis (older than E15.5) and early in postnatal development, cortically derived Emx1-lineage cells have been shown to migrate ventrally into the developing striatum (Willaime-Morawek et al., 2006; Willaime-Morawek and van der Kooy, 2008).

To directly examine whether pallial-derived Emxl-lineage cells indeed migrate from the pallium to the subpallium early in 

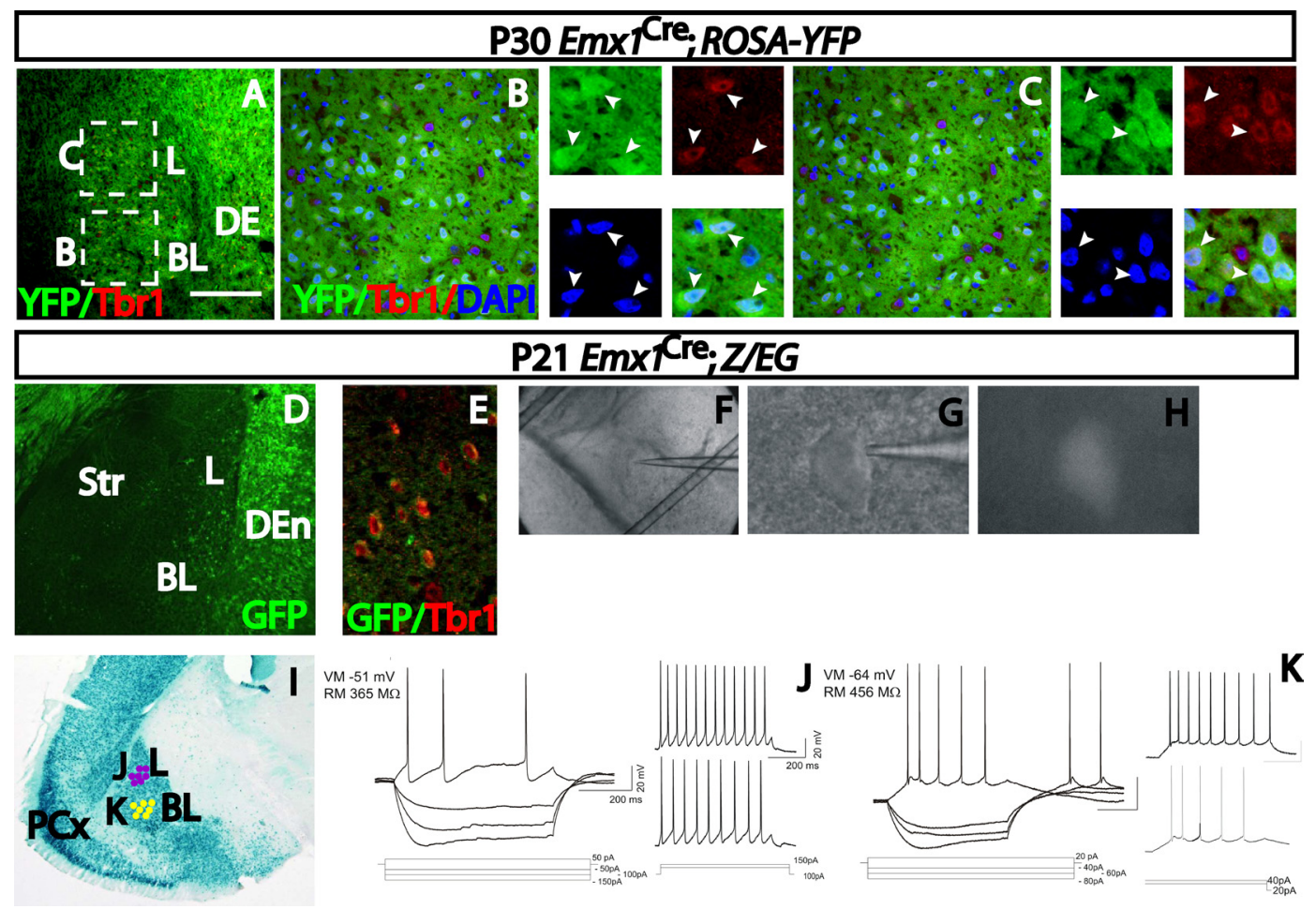

Figure 2. Emx1-lineage cells give rise to excitatory neurons in the basolateral complex of the amygdala. $A$, As shown at P30, YFP ${ }^{+}$Emx1-lineage cells are present throughout the basolateral and lateral nuclei of the amygdala. $\boldsymbol{B}, \boldsymbol{C}$, Higher-magnification optical sections of boxed regions of the lateral nucleus and basolateral nucleus shown in $\boldsymbol{A}$ reveal that $\mathrm{YFP}^{+}$cells in both of these nuclei also express Tbr1, a marker of excitatory neurons. (Arrowheads in $\boldsymbol{B}$ and Cshow YFP ${ }^{+} / \mathrm{Tbr}^{+}{ }^{+}$cells; DAPl is shown in blue). $\boldsymbol{D}-\boldsymbol{K}$, Cells of the amygdala in Emx 1 -Cre; Z/EG animals were also analyzed by immunohistochemistry $(\boldsymbol{D}, \boldsymbol{E})$ and by patch-clamp slice recordings at $P 21(\boldsymbol{F}-\boldsymbol{K})$. Emx1-lineage cells in Z/EG reporter animals $(\boldsymbol{D})$ also express Tbr 1 in the BLC $(\boldsymbol{E})$. Low magnification of a bright-field view of the amygdala $(\boldsymbol{F})$ shows location of recording. Higher magnification of bright field $(\boldsymbol{G})$ and fluorescent images $(\boldsymbol{H})$ illustrate a GFP ${ }^{+}$cell before patching. $\boldsymbol{I}$, Coronal section from an EmX1-Cre; ROSA-LacZ brain at the level of the basolateral complex shows many recombined cells in the lateral $(\boldsymbol{J})$ and basolateral $(\boldsymbol{K})$ amygdala. Colored circles illustrate the differential distribution of Emx 1 -lineage excitatory neurons identified by recordings in $\boldsymbol{J}$ and $\boldsymbol{K} . \boldsymbol{J}$, Traces from a representative GFP ${ }^{+}$cell in the lateral nucleus of the amygdala; all GFP ${ }^{+}$cells recorded in this nucleus exhibited a pyramidal-like firing pattern of action potentials $(n=7) . K$, Traces from a representative GFP ${ }^{+}$cell recorded in the basolateral nucleus; this population generated action potentials in a burst-firing pattern $(n=7)$. BL, Basolateral nucleus of the amygdala; L, lateral nucleus of the amygdala; DEn, dorsal endopiriform nucleus. Scale bars: (in $A), A-C, F, H, J, 300 \mu \mathrm{m} ; \boldsymbol{E}, \mathbf{G}, \boldsymbol{I}, 50 \mu \mathrm{m}$.

development, we placed DiI in the lateral and dorsal-lateral pallium of E11.5 (Fig. $4 A-F$ ) and E13.5 (Fig. 4G-L) Emx1-Cre; ROSA-YFP brains and cultured for $36-48 \mathrm{~h}$ in vitro. DiI ${ }^{+}$cells were observed migrating into the dLGE, thus confirming that pallial progenitors had the capacity to migrate ventrally. We also observed $\mathrm{DiI}^{+} / \mathrm{YFP}^{+}$Emxl-lineage cells migrating ventral-laterally from the dorsal-lateral pallium into the ventral pallium and LGE (Fig. $4 D-F, J-L)$.

To further examine this migratory path using an in vivo assay, we electroporated the dorsolateral pallium in utero at E12.5 with a construct that constitutively expresses RFP in electroporated cells. Three days later, at E15.5, we observed $\mathrm{RFP}^{+}$cells that had migrated away from the site of electroporation in the dorsolateral pallium and toward the ventral telencephalon (Fig. $4 M, N$ ), consistent with previous work showing pallial-to-subpallial migration using in utero electroporations (Bai et al., 2008; Soma et al., 2009). This observation was also consistent with our in vitro findings of an early pallial-to-subpallial migratory wave. From our long-term analysis of cortically electroporated brains, we also found a small number of $\mathrm{RFP}^{+}$cells in the dorsal striatum (Fig. 4O-Q).

Although the above evidence revealed that Emx1-lineage cells migrate from the pallium to the subpallium, we wanted to examine whether some of these cells might also be locally derived. To accomplish this, we labeled Emx1-Cre; ROSA-YFP embryos with a short pulse of BrdU at either E11.5 or E13.5, and killed after $2 \mathrm{~h}$ (supplemental Fig. 3, available at www.jneurosci.org as supple- mental material). We reasoned that any $\mathrm{BrdU}^{+}$cells in the LGE would most likely be derived locally as $2 \mathrm{~h}$ would not be enough time for a pallial-derived cell population to migrate ventrally into the LGE. Interestingly, a few Emx1-lineage cells in the LGE were also heavily labeled with BrdU at E13.5, although not at E11.5, suggesting that at E13.5 there may also be a locally derived $E m \times 1^{+}$ population. Thus, in addition to arising from the pallium, it is likely that a small subpopulation of $E m x 1^{+}$cells present in the LGE at E13.5 and later were locally derived. This finding is also consistent with a recent study revealing that Emx1-Cre mice have the capacity to recombine in subpallial Gsx2-positive cells (Waclaw et al., 2009).

Generation of MSNs from $E m x 1^{+}$pallial progenitors in vitro Given the above evidence that dorsal Emx1-lineage cells were able to migrate ventrally, and that pallial RFP-labeled cells were found in the postnatal striatum, we next sought to determine whether pallial-derived Emxl-lineage cells had the capacity to generate striatal MSNs. To accomplish this, we dissected distinct domains of the E13.5 Emx1-Cre; ROSA-YFP pallium and LGE (schema shown in supplemental Fig. $4 E$, available at www.jneurosci.org as supplemental material) and allowed them to differentiate into neurons in vitro. Differentiated MSNs were identified by triple immunostaining with YFP, CTIP2 and GAD65/67 (supplemental Fig. 4, available at www.jneurosci.org as supplemental material). We found that Emxl-lineage cells from the medial pallium were inefficient at producing MSNs, while cells taken from 


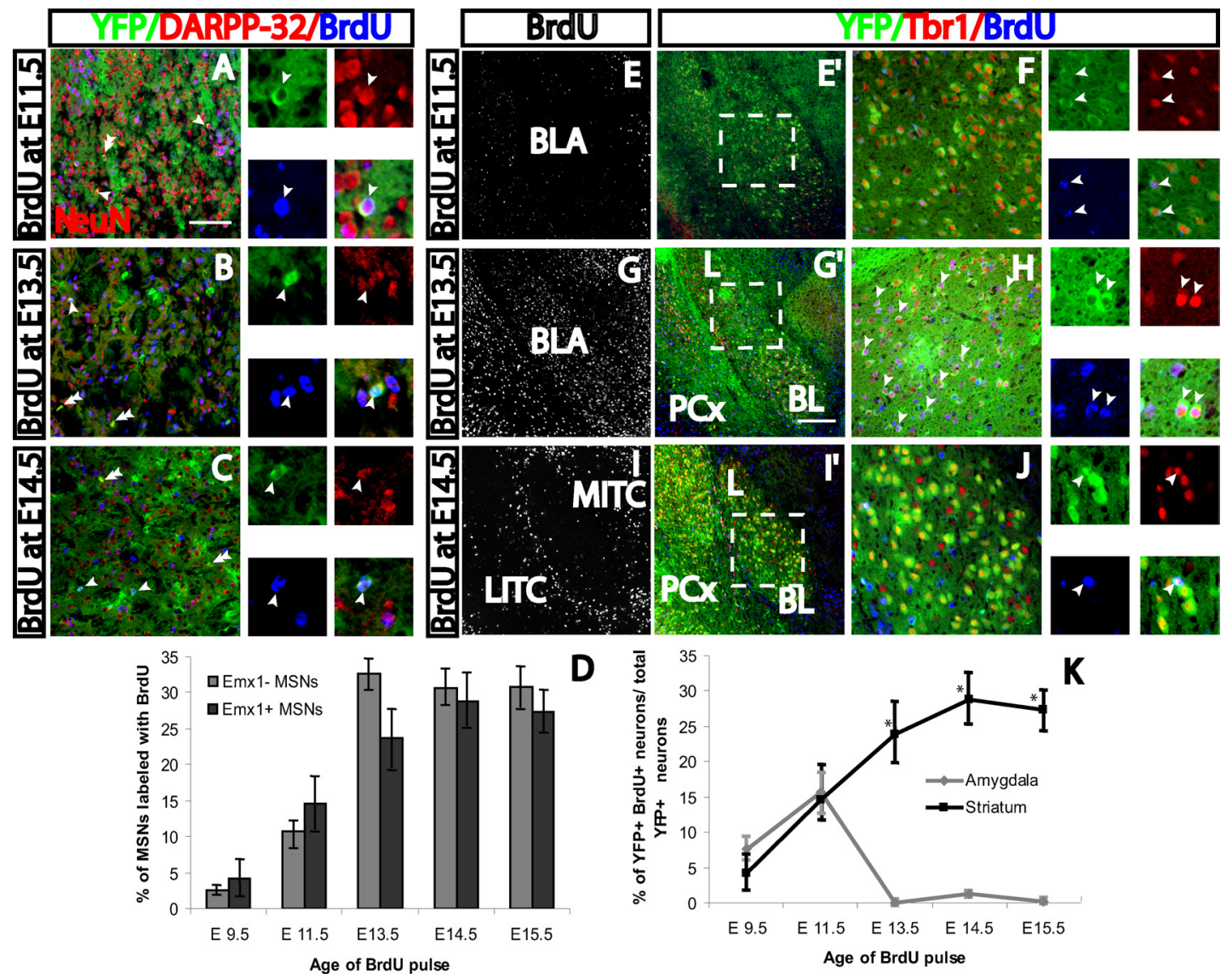

Figure 3. Differential birth dates of Emx1-lineage cells in the striatum and amygdala. $A$, BrdU administration at E11.5 labels Emx1-lineage neurons in the dorsal striatum at P15 (arrowheads point to a BrdU ${ }^{+} / \mathrm{YFP}^{+} / \mathrm{DARPP}-32^{+}$cell; double arrowheads point to a BrdU $-/ \mathrm{YFP}^{+} / \mathrm{NeuN}^{+}$cell). $\boldsymbol{B}$, Administration of BrdU at E13.5 results in more YFP ${ }^{+}$cells double-labeled. (Arrowheads point to a BrdU ${ }^{+} / \mathrm{YFP}^{+} / \mathrm{NeuN}^{+}$cell; double arrowheads point to a BrdU ${ }^{-} / \mathrm{YFP}^{+} / \mathrm{NeuN}^{+}$cell). C, BrdU administration at E14.5 results in many colabeled Emx1-lineage cells at P15. (Arrowheads point to $\mathrm{BrdU}^{+} / \mathrm{YFP}^{+} / \mathrm{DARPP}-32^{+}$cells; double arrowheads point to $\mathrm{BrdU}^{-} / \mathrm{YFP}^{+} / \mathrm{DARPP}-32^{+}$cells). D, Quantification of striatal birth dates. For Emx7-lineage MSNs, percentages were calculated by dividing the total number of YFP ${ }^{+}$(or YFP ${ }^{-}$)/DARPP- $32^{+} / \mathrm{BrdU}^{+}$cells by the number of YFP ${ }^{+}$(or YFP ${ }^{-}$)/DARPP- $32^{+}$cells for each age; for Emx 1 -negative MSNs percentages, YFP $^{-}$cells in the same sections were quantified. Emx 1 -lineage MSNs: 4\% $(4 / 103, n=3)$ at E9.5, 15\% $(9 / 59, n=2)$ at E11.5, 23\% $(15 / 63, n=2)$ at E13.5, 29\% $(21 / 78, n=3)$ at E14.5, and $27 \%$ $(14 / 50, n=2)$ at E15.5. Emx1-negative MSNs: $3 \%(86 / 3339, n=3)$ at E9.5, $11 \%(355 / 3221, n=2)$ at E11.5, at E13.5, 33\% $(670 / 2032, n=2)$, at E14.5, 31\% $(1272 / 4093, n=3)$, and $27 \%$ $(703 / 2261, n=2)$ at E15.5. $E, F$, In the amygdala, BrdU labels $7 \%$ of Tbr ${ }^{+} / \mathrm{NFP}^{+}$cells at E9.5. $\boldsymbol{E}$, BrdU alone; few cells are labeled in the basolateral nucleus (BL) at E9.5. $\boldsymbol{E}^{\prime}$, Low-power image of the basolateral nucleus. $\boldsymbol{F}$, Higher-magnification single optical sections of boxed section in $\boldsymbol{E}^{\prime}$; single arrowheads point to triple-labeled BrdU ${ }^{+} / \mathrm{Tbr}^{+}{ }^{+} \mathrm{YFP}^{+}$cells; double arrowheads point to $\mathrm{BrdU}^{-} / \mathrm{YFP}^{+} / \mathrm{Tbr}^{+}{ }^{+}$cells. $\mathbf{G}, \boldsymbol{H}, \mathrm{BrdU}$ administration at E11.5; $\mathrm{BrdU}^{+}$cells are present throughout the BLA. BrdU-labeled Emx7-lineage cells are present throughout both the BL and lateral nucleus (L) (26.4\% of YFP ${ }^{+} / \mathrm{Tbr}^{+}{ }^{+}$cells were also heavily labeled with BrdU); arrowheads in $\mathrm{H}$ point to BrdU ${ }^{+} / \mathrm{YFP}^{+} / \mathrm{Tbr} 1^{+}$cells. I, J, BrdU at E13.5; in the BLA very few cells are BrdU labeled. However, intercalated cell masses both medially and laterally are heavily labeled by $\operatorname{BrdU}(\boldsymbol{I})$. Low-power $\left(I^{\prime}\right)$ and higher-power $(\boldsymbol{J})$ optical sections show that few Emx1-lineage cells are labeled with BrdU at E13.5 in the $\mathrm{BL}\left(1.5 \%\right.$ of YFP ${ }^{+} / \mathrm{Tbr}^{+}{ }^{+}$cells were heavily labeled) (arrowheads point to the only BrdU ${ }^{+} / \mathrm{YFP}^{+} / \mathrm{Tbr} 1^{+}$cell in the section). $\boldsymbol{K}$, Graph of the percentages of striatal-and amygdala-fated Emx1-lineage BrdU ${ }^{+}$cells born at different times during embryogenesis. In the amygdala, 7\% were born at E9.5 (48/731, $\left.n=6\right), 14 \%$ at E11.5 $(89 / 741, n=6), 2 \%$ at E13.5 (9/555, $\left.n=3\right), 1 \%$ at E14.5 $(7 / 279, n=3)$, at $0.1 \%$ at E15.5 $(1 / 608, n=3)$. LITC, Lateral intercalated cells; MITC, medial intercalated cells; PCX, piriform cortex. Scale bars: (in $A), A-C, F, H, J, 100 \mu \mathrm{m} ; \boldsymbol{E}, \mathbf{G}, I, 150 \mu \mathrm{m}$.

either the dorsal pallium or the region of the ventral/lateral pallium were able to produce MSNs with a greater efficiency (supplemental Fig. $4 A-C, F$, available at www.jneurosci.org as supplemental material). In contrast, Emxl-lineage cells in the LGE were not as efficient at making MSNs as cells taken from the dorsal or ventral/lateral pallium (supplemental Fig. 4D, F, available at www.jneurosci.org as supplemental material). Thus, this in vitro data revealed that embryonic Emxl-lineage cells derived from the pallium have the capacity to generate MSNs.

\section{Differential combinatorial gene expression in striatal and} amygdala $E m x 1$ lineages

Once we established that Emx1-lineage cells were able to migrate ventrally from the pallium and had the potential to become inhibitory MSNs, we sought to determine whether subpallial Emx1lineage cells were expressing genes characteristic of their putative pallial origin or of their new subpallial location. To accomplish this, sections from Emx1-Cre; ROSA-YFP embryos were coimmunostained for YFP and individually for the subpallial markers Gsx2 and Dlx2, or the pallial markers Pax6 and Tbr1. At E11.5 Emx1-lineage cells in the LGE were predominately found in the dLGE, and were also present near the pallial-subpallial border (PSB) (Fig. 5A). These cells coexpressed the subpallial ventricular zone (VZ) homeobox transcription factor Gsx2 (Fig. 5B). By E13.5, many more cells were present throughout the LGE, and these cells had leading processes extending in multiple directions, suggesting that they were moving between the LGE mantle, subventricular zone (SVZ), and VZ (Fig. $5 C, D, D^{\prime}$ ). These Emx1lineage cells also expressed Gsx2 in the VZ, and in addition, coexpressed Dlx2, a homeobox transcription factor expressed in the VZ and SVZ of the subpallium (Fig. $5 E, F$ ). These data indicate that, in contrast to the Emxl-lineage cells that remain in the pallium, the subpopulation of Emxl-lineage cells that are present 
in the LGE express subpallial genes characteristic of their new environment.

We further examined whether Emx1lineage cells located in the subpallium continued to express pallial genes consistent with their probable pallial origin. We immunolabeled E11.5 and E13.5 sections with Pax6, and found that some Emx1lineage cells at the ventral pallial aspect of the PSB continued to express Pax6 protein. However, consistent with their expression of subpallial markers as shown above, cells in the LGE VZ and SVZ did not express Pax6 (Fig. 5G, J,K). We also examined sections more caudally at the level of the caudal ganglionic eminence and the developing amygdala. While Pax6 was not expressed at this plane of section in the amygdala primordium at detectable levels (data not shown), Tbr1, a marker of the excitatory neuronal lineage, was highly expressed, and most Emx1-lineage cells at this age expressed Tbr1 in the amygdala primordium and piriform cortex, but not in the dLGE or ventral palliumVP (Fig. $5 H, I, L, M$ ) (data not shown).

As our above evidence collectively indicates that pallial-derived $E m \times 1^{+}$progenitors contribute to both excitatory and inhibitory neuronal populations in the basal telencephalon, we next sought to determine whether interaction with the PSB, a region through which many of these cells presumptively migrate, is important in the regulation of this differential fate. To accomplish this, we examined the status of Emx1-lineage cells in loss of Pax6 function (Sey/Sey; Small eye) mice in which the PSB is severely disrupted (Fig. 6 ). In these mutants, proliferation is increased in the cortex, differentiation is impaired, migration out of the pallial VZ is reduced, and migration at the PSB is abnormal (Schmahl et al., 1993; Carić et al., 1997; Chapouton et al., 1999; Warren et al., 1999; Quinn et al., 2007; Carney et al., 2009). We found an increased number of Emx1-lineage progenitors in the LGE of Emx1-Cre; Sey/Sey mice at E13.5, although this difference was not apparent at earlier ages (Fig. 6A-D). Analysis at E17.5, when many LGE progenitors have already differentiated into MSNs, revealed that there were increased numbers of CTIP $2^{+} /$Emx1-lineage cells in the striatal primordium in Emx1-Cre; Sey/Sey mice compared with control mice (Fig. $6 E, F)$. In contrast, in the developing amygdala, the number of $\mathrm{Tbr} 1^{+} / \mathrm{YFP}^{+}$ neurons was not different between controls and Sey/Sey mice at either E13.5 or E17.5 (Fig. 6G-J). These data indicated that there was not an obvious defect in
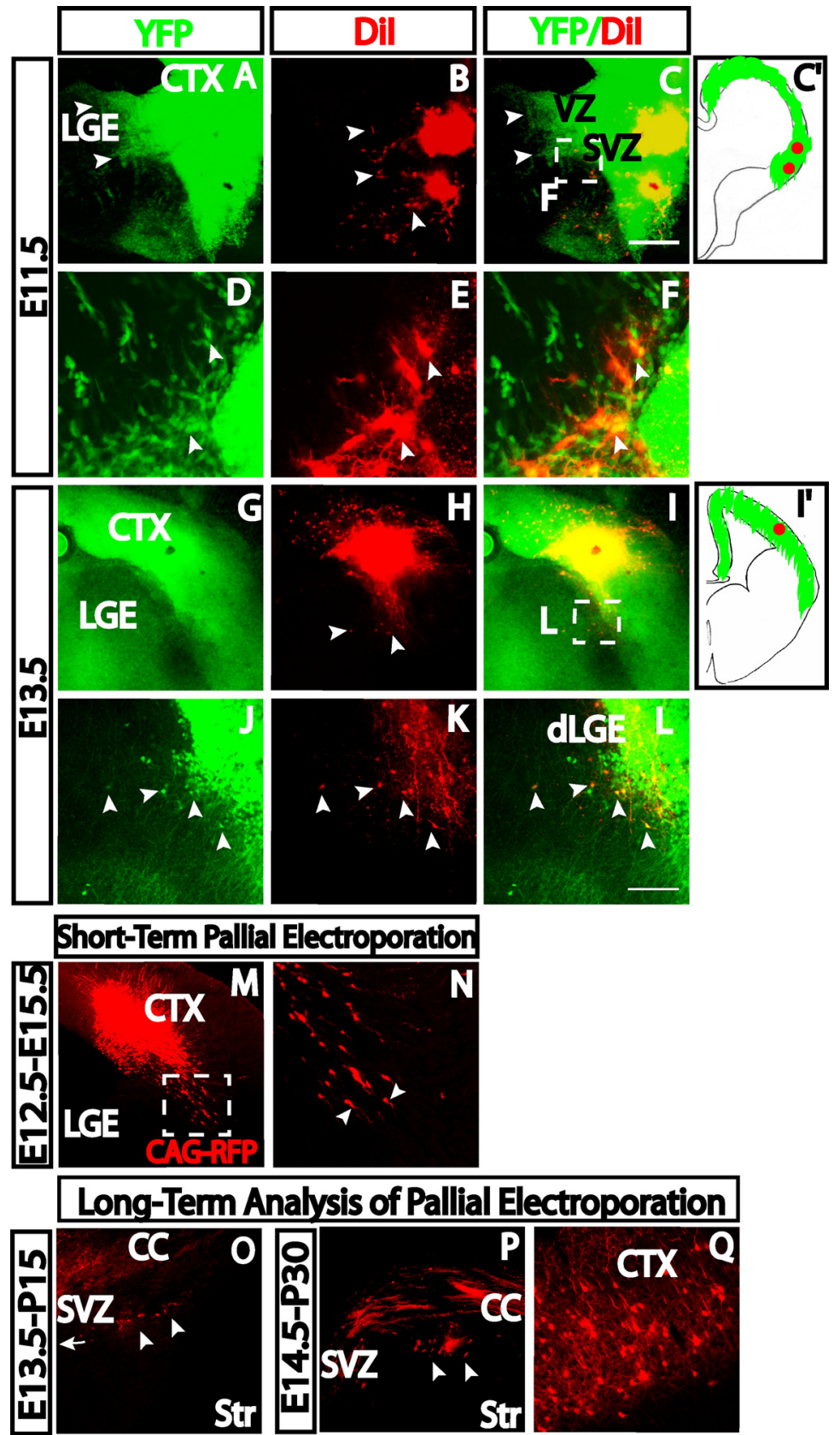

Figure 4. A subpopulation of Emx1-lineage progenitors migrates ventrally from the developing cerebral cortex into the LGE during early neurogenesis. $\boldsymbol{A}-\boldsymbol{C}$, Low-power images of a coronal Emx1-Cre; ROSA-YFP slice show Dil placement at E11.5 in the lateral pallium (arrowheads mark cells that have migrated). $\boldsymbol{C}^{\prime}$, Dil crystal location. $\boldsymbol{D}-\boldsymbol{F}$, Higher magnification of the boxed region in $C$ reveals that a subpopulation of $\mathrm{Dil}^{+}$cells has migrated from the lateral pallium to the ventral pallium and LGE. Arrowheads point to several cells that have migrated ventrally that are also YFP ${ }^{+}$. Eighty-three percent $(5 / 6)$ of the slices had ventrally migrating Dil-labeled cells that also colabeled with YFP. G-I,I', Dil placed in the lateral pallium atE13.5 also reveals cells migrating ventrally into the VP and LGE. $J-L$, Higher magnification of the boxed region in $I$; arrowheads point to Dil $^{+} / \mathrm{YFP}^{+}$cells in the LGE. Sixty-seven percent (4/6) of the slices had ventrally migrating Dil-labeled cells that also colabeled with YFP. $\boldsymbol{M}-\mathbf{Q}$, Embryos were electroporated in utero with $4 \mu \mathrm{g} / \mu$ I CAG-RFP plasmid. The lateral pallium was specifically targeted at embryonic ages as indicated, and embryos were killed 3 d later (E15.5), at P15, or at P30.M, N, Short-term analysis of electroporated brains shows that the electroporation was targeted specifically in the lateral pallium. $\boldsymbol{N}$, Higher magnification of the boxed region in $\boldsymbol{M}$ shows cells with ventrally oriented leading processes (arrowheads) ( $n=5$ electroporations). $\mathbf{O}$, Coronal sections of a P15 animal electroporated at E13.5; RFP ${ }^{+}$cells are present in the dorsal striatum near the SVZ $(n=3) . P$, Coronal section of a P30 animal electroporated at E14.5; cells are present in the dorsal striatum. $\mathbf{Q}$, Image of the adjacent cortex; RFP ${ }^{+}$cells are present in the upper layers of the cortex, indicating correct embryonic dorsal pallium targeting $(n=2)$. Scale bars: (in $\boldsymbol{C}), \boldsymbol{A}-\boldsymbol{C}, 250 \mu \mathrm{m} ; \boldsymbol{D}-\boldsymbol{F}, 50 \mu \mathrm{m}$; (in $\mathbf{L}$ ), $\mathbf{G}-\mathbf{I}, 250 \mu \mathrm{m} ; \boldsymbol{J}-\mathbf{L}, 125 \mu \mathrm{m} ; \boldsymbol{M}, 160 \mu \mathrm{m} ; \boldsymbol{N}, 80 \mu \mathrm{m} ; \mathbf{0}-\mathbf{Q}, 100 \mu \mathrm{m}$. 

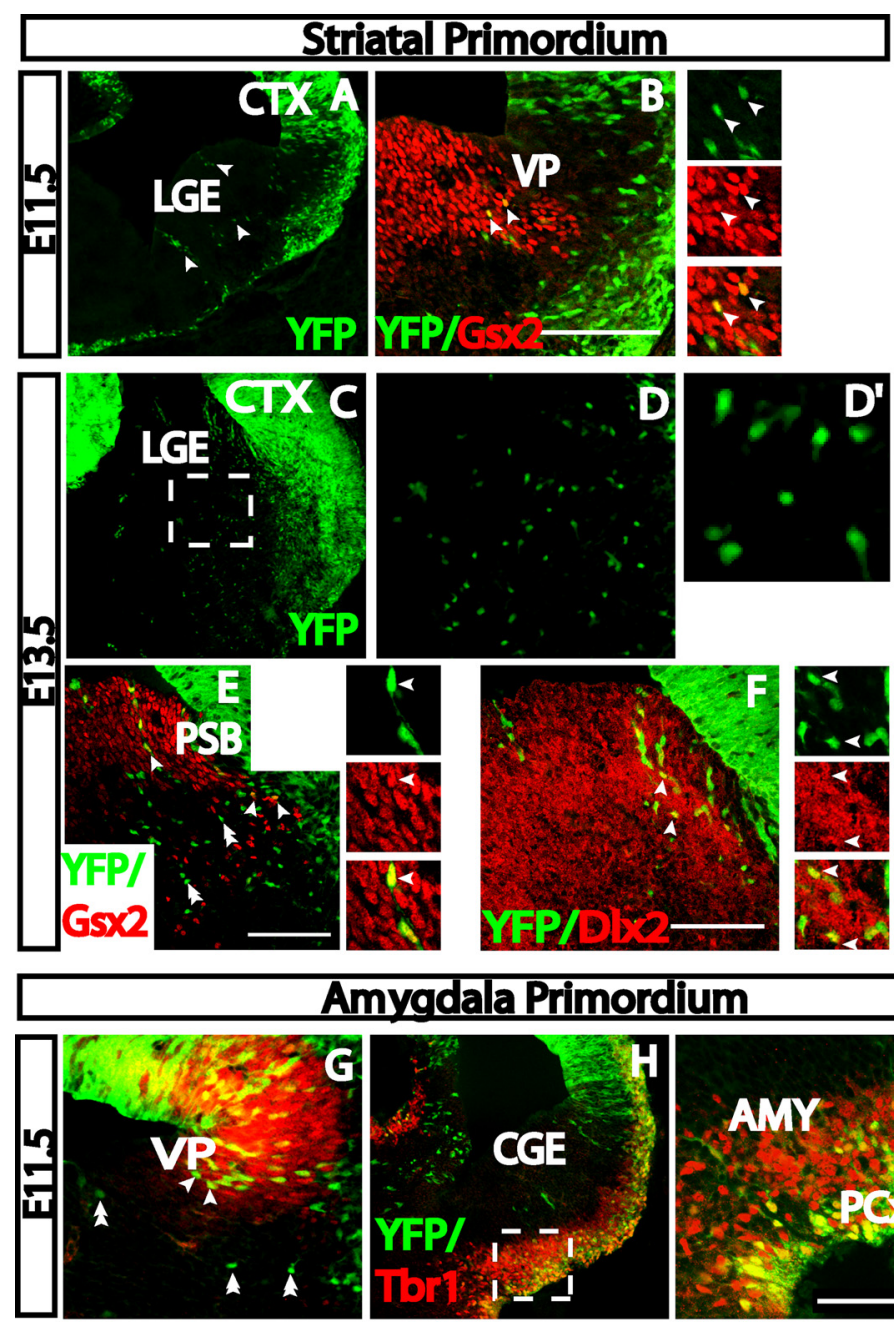

Amygdala Primordium
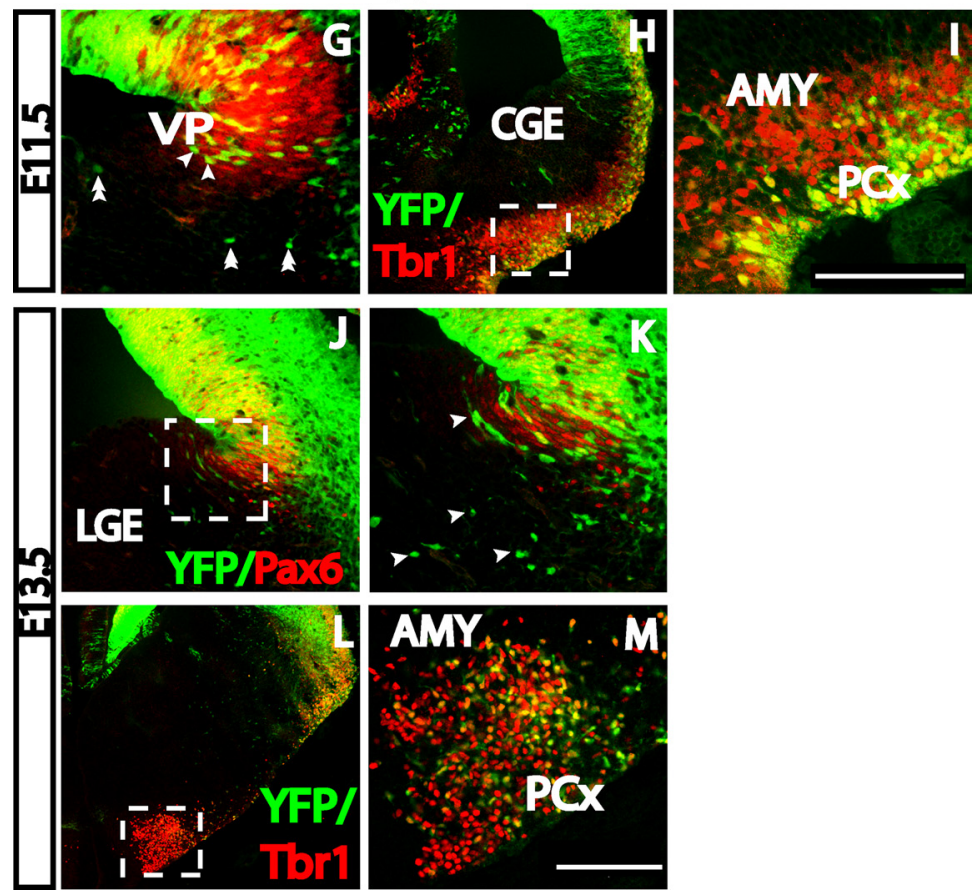

Figure 5. Expression of subpallial and pallial markers in Emx1-lineage cells during embryogenesis correspond to their basal telencephalic location. $\boldsymbol{A}$, Confocal images from sections from Emx1-Cre; ROSA-YFP brains illustrate that several Emx1-lineage cells are present at E11.5 in the dLGE in both the VZ and SVZ (arrowheads). $B$, YFP ${ }^{+}$cells in the dLGE express GsX2, which marks the VZ of the subpallium. Arrowheads in $\boldsymbol{B}$ show YFP ${ }^{+} / G s \times 2^{+}$cells. $\boldsymbol{C}, \boldsymbol{D}$, By E13.5, many Emx1-lineage cells are present in the LGE. $\boldsymbol{D}$, Higher magnification of the boxed region in $\boldsymbol{C} \boldsymbol{E}, \boldsymbol{F}$, Confocal optical images reveal that a subpopulation of YFP ${ }^{+}$cells in the LGE expresses the subpallial transcription factors Gsx2 $(\boldsymbol{E})$ and DlX2 $(\boldsymbol{F})$ (arrowheads show double-labeled cells and double arrowheads show YFP ${ }^{+}$cells only). G, Optical sections reveal that Emx1-lineage cells in the dLGE atE11.5 do not express the pallial marker Pax6 (double arrowheads). However, Emx1-lineage cells in the VP are also Pax6 ${ }^{+}$(arrowheads). $\boldsymbol{H}, \boldsymbol{I}$, Low-power optical section $(\boldsymbol{H})$ and higher-power optical section of boxed region in $\boldsymbol{H}(\boldsymbol{I})$ showing that recombined cells are also present more caudally in the region of the developing piriform cortex and amygdala. Many of these cells are Tbr ${ }^{+}{ }^{+} \boldsymbol{J}, \boldsymbol{K}$, By E13.5, many YFP ${ }^{+}$cells are present beyond the Pax6 ${ }^{+}$ventral pallium and are located in the LGE in both the VZ and the SVZ. $\boldsymbol{K}$, Higher-magnification optical section of boxed region in $J$ reveals that in the LGE, YFP ${ }^{+}$cells do not colabel with Pax6 (arrows). $L, M$, In the more caudal regions, including the presumptive amygdala, many Emx1-lineage cells are present, and most express Tbr1. Higher-magnification optical proliferation, migration, or fate of Emx1lineage cells in the amygdala. Therefore, disruption of the PSB results in an increase in the numbers of Emx1-derived MSNs in the striatum, but not the amygdala, indicating a role for Pax6 in one or more of several developmental processes: (1) determination of the dorsal to ventral migratory route of Emxl-lineage cells to the LGE, (2) regulation of the fate of these cells in the striatum, or (3) regulation of the size of the Emx1-derived MSN progenitor pool.

Our above analyses of gene expression profiles of Emx1-lineage cells during embryogenesis (Fig. 5) revealed what appeared to be two distinct pools of basal telencephalic Emx1-lineage cells: ones that express subpallial markers and presumably contribute to the striatum to generate MSNs, and ones that maintain expression of pallial markers and contribute to excitatory neurons in the amygdala. To directly examine whether Emx1-lineage cells that also expressed subpallial transcription factors had a different fate in the basal telencephalon than Emx1-lineage cells that did not express subpallial transcription factors, we used an intersectional genetic fate-mapping approach (Kim and Dymecki, 2009) in which Emx1-Cre mice were crossed to Dlx5/6Flpe mice (Miyoshi and Fishell, unpublished observations). Their progeny were crossed to RCE: dual reporter mice, which express EGFP only when both Cre and Flpe have been expressed in the same cell (Sousa et al., 2009). During embryogenesis, we found that Emx1; Dlx-lineage cells were remarkably restricted to the LGE and not present in other telencephalic regions (Fig. $7 A, B$ ). Many of these cells were labeled with the neuronal progenitor marker TUJ1 (Fig. 7C,D). Consistent with the restricted pattern of cell distribution in the embryonic brain, we observed that in the postnatal brain Emxl; Dlx-lineage cells were found almost exclusively in the postnatal striatum (Fig. 7E) and were notably absent from the amygdala (data not shown). Furthermore, Emx1; Dlx-lineage cells expressed DARPP-32 and NeuN, but did not express markers for glial cells or interneurons, indicating that they were also restricted in their cellular fate (Fig. $7 F-I)$ (data not shown). Thus, EmxI-

$\leftarrow$

section of boxed region in $L$ is shown in $\boldsymbol{M}$. Scale bars: (in $\boldsymbol{B}), \boldsymbol{A}$, $\boldsymbol{C}, \boldsymbol{H}, \boldsymbol{L}, 300 \mu \mathrm{m} ; \boldsymbol{B}, \mathbf{G}, \boldsymbol{K}, 200 \mu \mathrm{m}$; (in $\boldsymbol{E}$ ), $\boldsymbol{E}, 100 \mu \mathrm{m}$; (in $\boldsymbol{F}$ ), $\boldsymbol{F}$, $100 \mu \mathrm{m}$; (in I), $\boldsymbol{I}, 100 \mu \mathrm{m}$; (in $\boldsymbol{M}$ ), $\boldsymbol{M}, 100 \mu \mathrm{m}$. AMY, Amygdala, CGE, caudal ganglionic eminence; $P C x$, presumptive piriform cortex; Str, striatal primordium. 


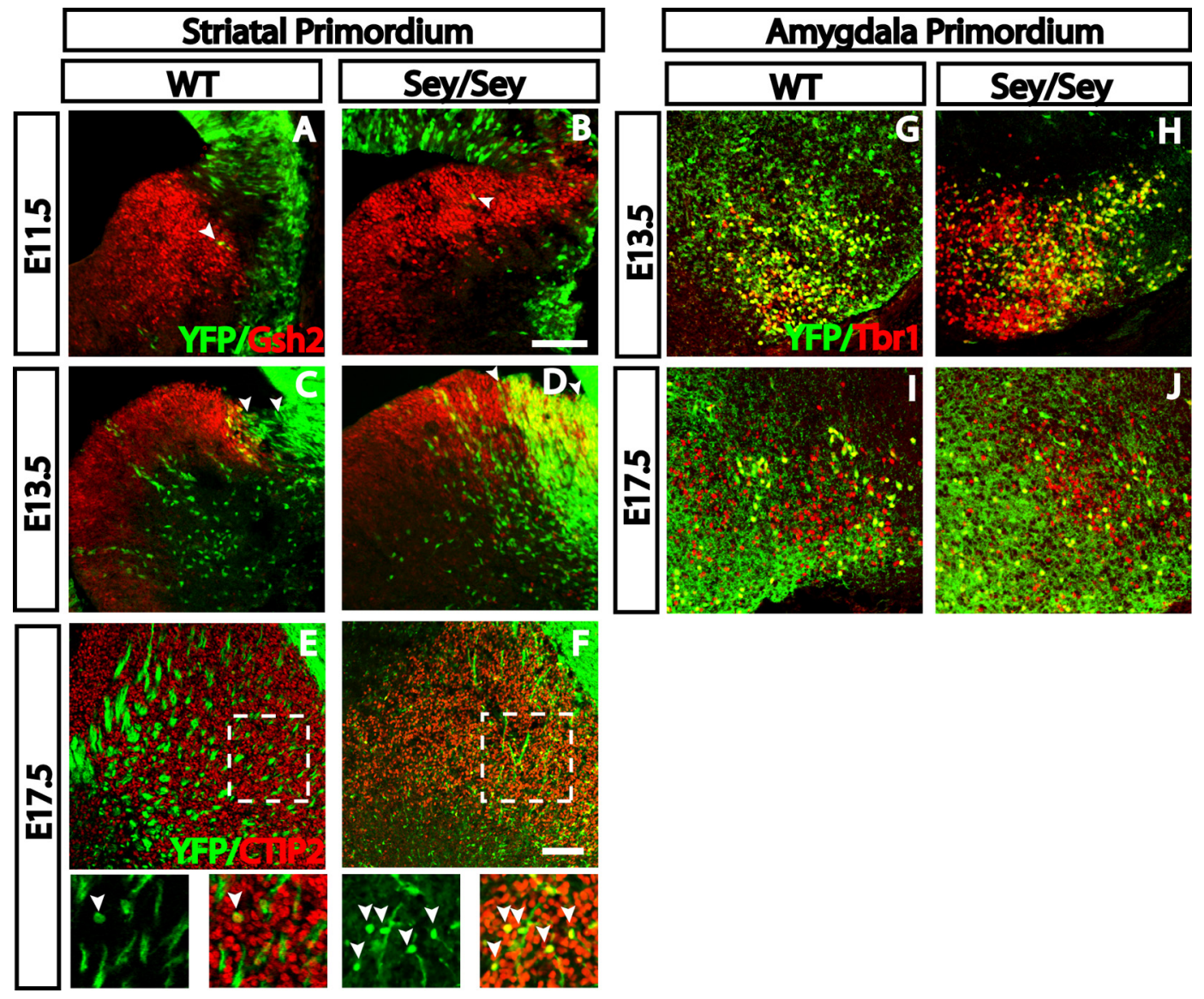

Figure 6. Disruption of the PSB in Sey/Sey mice alters the number of Emx1-lineage cells in the striatal primordium but not in the amygdala primordium. $\boldsymbol{A}$, Wild-type (WT) E11.5 Emx1-Cre; ROSA-YFP section labeled with Gsx2; a few YFP ${ }^{+} / G s \times 2{ }^{+}$cells are present in the LGE. $B$, In the Sey mutant, Gsx2 protein expands dorsally, and few Emx 7 -lineage cells are present in the LGE. C, In the WT E13.5 mouse; YFP ${ }^{+}$cells colabel with GsX2 in the VZ of the LGE. D, In the E 13.5 Sey mutant, the number of YFP ${ }^{+}$cells is ectopically expanded past the PSB (arrowheads), and Gsx2 expression is expanded dorsally, but there is no change in the number of YFP ${ }^{+}$cells or their position in the LGE (110 CTIP2 ${ }^{+} / \mathrm{YFP}^{+}$cells in $n=3$ WT, 108 CTIP2 ${ }^{+} / \mathrm{YFP}^{+}$cells in $n=3$ mutants). E, At E17.5 in the WT mouse, scattered YFP ${ }^{+} / \mathrm{CTIP2}^{+}$cells are present in the dorsal-lateral striatum and many YFP ${ }^{+}$cortical fibers are visible in the dorsal-medial striatum (see inset); few CTIP2 ${ }^{+}$cells are $\mathrm{YFP}^{+}$(arrowheads). $\boldsymbol{F}$, In the Sey mutant, significantly more CTIP2 ${ }^{+} / \mathrm{YFP}^{+}$cells (arrowheads) are present (see inset), and the $\mathrm{YFP}^{+}{ }^{+}$cortical fibers are markedly diminished; $\mathrm{CTIP2}^{+}$YFP ${ }^{+}$cells in mutants are $182 \%$ of CTIP2/YFP ${ }^{+}$cell numbers in controls, $p<0.05\left(95\right.$ CTIP2 $^{+} / \mathrm{YFP}^{+}$cells in $n=3 \mathrm{WT}$, $173 \mathrm{CTIP2}^{+} / \mathrm{YFP}^{+}$cells in $n=3$ mutants $)$. G, AtE13.5, the WT amygdala primordium contains many YFP ${ }^{+} / \mathrm{Tbr}^{+}{ }^{+}$cells. $\boldsymbol{H}$, In the Sey mutant, numerous $\mathrm{YFP}{ }^{+}$cells are still present. $\boldsymbol{I}, \boldsymbol{J}$, In addition, $\mathrm{YFP}^{+} / \mathrm{Tbr} 1^{+}$cells are present in both WT and mutants at E17.5. Quantification of E13.5 and E17.5 revealed no significant differences in the numbers of YFP ${ }^{+}$cells in the amygdala primordium [Sey mutants had $102 \%$ of control Tbr $1^{+} / \mathrm{YFP}^{+}$cell numbers at E13.5 $\left(415\right.$ Tbr ${ }^{+} / \mathrm{YFP}$ cells in Sey/Sey mice, $n=3,405 \mathrm{Tbr} 1^{+} / \mathrm{YFP}$ cells in WT mice, $\left.n=3\right)$ and $115 \%$ of controls at E17.5 $\left(233 \mathrm{Tbr} 1^{+} / \mathrm{YFP}\right.$ cells in Sey/Sey mice, $n=3,202 \mathrm{Tbr} 1^{+} / \mathrm{YFP}$ cells in WT mice, $\left.\left.n=3\right)\right]$; these differences were not statistically significant. Scale bars: (in $\boldsymbol{B}$ ), $\boldsymbol{A}-\boldsymbol{D}, 100 \mu \mathrm{m}$; (in $\boldsymbol{F}$ ), $\boldsymbol{E}-\boldsymbol{J}, 100 \mu \mathrm{m}$.

lineage neurons that express $D l x$ genes during development exclusively give rise to an MSN subpopulation in the striatum.

\section{Discussion}

Emx1 lineage contribution to the striatum and amygdala

In this study, using a combination of approaches, we investigated the timing, fate and origins of Emx1-lineage cells in the striatum and amygdala, two major structures of the basal telencephalon. In relation to fate, most prominently, our immunohistochemical and electrophysiological characterization in the striatum reveals that Emx1-lineage neurons in the striatum comprise a subset of striatal MSNs. Emx1-lineage striatal neurons display a number of specific characteristics distinct from non-Emx1 lineage MSNs. First, striatal Emx1-lineage cells, while present throughout the dorsal-ventral and rostral-caudal axes, are disproportionately localized in the dorsal portion of the striatum, which receive connections from neurons in deep layer V of the cortex. Emx1lineage MSNs are also preferentially localized to the patch (striosome) compartment of the striatum. Patch neurons receive inputs primarily from the limbic cortex, in contrast to matrix neurons, which receive inputs primarily from neocortical areas
(Gerfen, 1984; Donoghue and Herkenham, 1986). Previous work has also shown that one of the targets of patch neurons is the basolateral nucleus of the amygdala, indicating that this Emx1lineage subpopulation may be an important subcomponent of a limbic circuit that modulates information between the cortex and amygdala (Ragsdale and Graybiel, 1988). It is interesting to note that while Emx1-lineage neurons contribute mainly to patches in the striatum our BrdU analysis indicates that this cell population is born throughout striatal development. As previous work has shown that patch neurons are born earlier than matrix neurons (Fishell and van der Kooy, 1987; Fishell et al., 1990; Krushel et al., 1993; Song and Harlan, 1994; Krushel et al., 1995; Olsson et al., 1997; Mason et al., 2005) our data interestingly suggest that Emx1-lineage neurons may produce patch neurons over a longer period of time than the Emx1-negative MSN progenitor pool.

Intriguingly, our results also indicate that, in addition to the LGE, at least a subpopulation of the Emx1-lineage MSNs of the striatum appear to be derived from the embryonic pallium, a region not previously recognized as a source of basal telencephalic inhibitory projection neurons. The LGE origin is sup- 


\section{Emx1 Cre, Dlx5/6Flpe; RCE: dual}
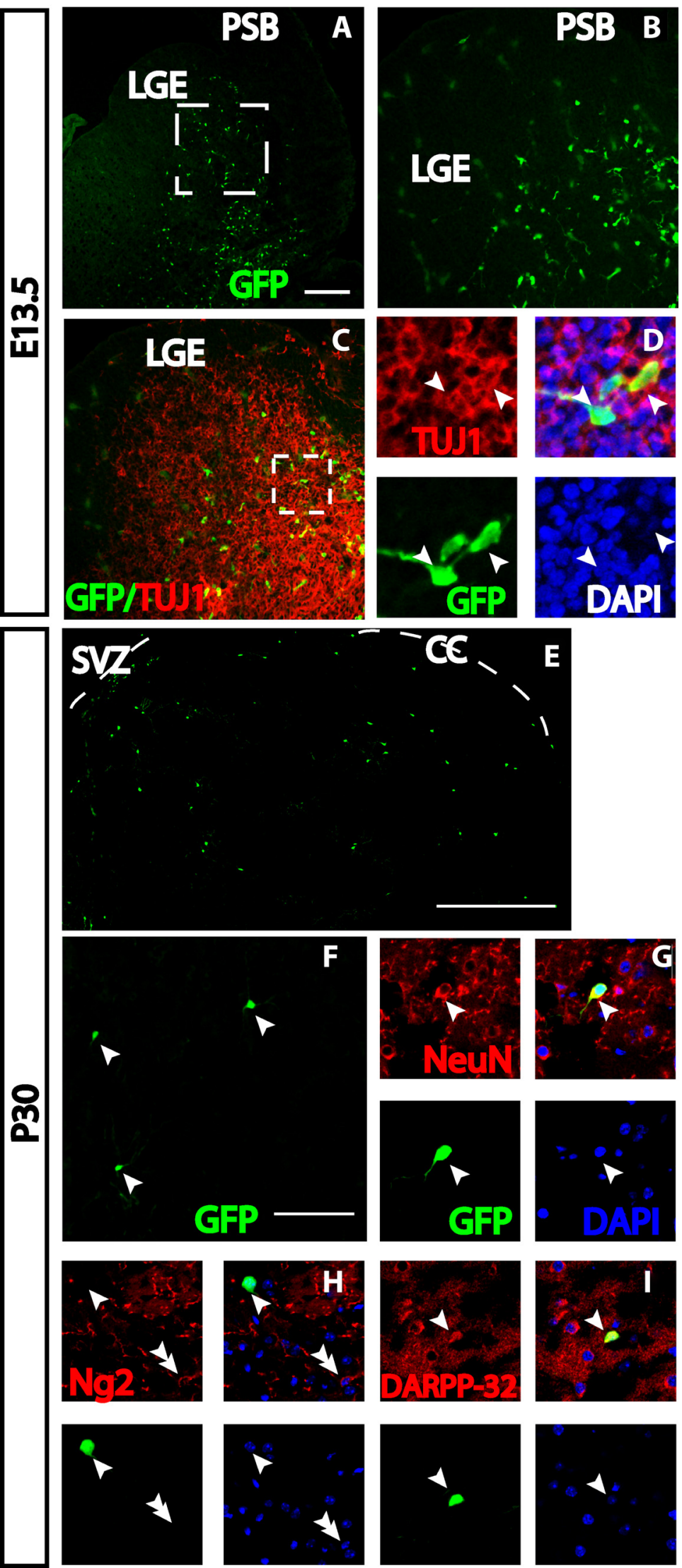

Figure 7. Cells derived from Emx1 and D/x combinatorial lineages are present in the embryonic LGE and contribute exclusively to the postnatal striatum. $\boldsymbol{A}, \boldsymbol{B}, \mathrm{At} \mathrm{E} 13.5, \mathrm{GFP}^{+} \mathrm{Emx1}$; Dlx-lineage cells are present throughout the SVZ and mantle of the LGE. ported by our short-term BrdU birthdating experiments which reveal some Emx1-lineage dividing cells in the VZ of the LGE at E13.5 (but not E11.5), as well as recent work has shown that Emx1-Cre mice can be used to recombine cells in the LGE (Waclaw et al., 2009). However, we suggest that an early-generated $E m \times 1^{+}$ progenitor pool from the developing cerebral cortex is also an important source of striatal neurons. Our evidence for this is as follows: (1) at embryonic stages we find that Emx1-lineage cells are present in regions that extend beyond the pallial Emx 1 mRNA-expressing domain, suggestive of an active migration ventrally; (2) our in vitro and in vivo migration assays reveal that Emx1-lineage cells from the pallium migrate ventrally into the LGE and striatum, respectively; (3) our in vitro differentiation assay indicates that the E13.5 pallium has the capacity to generate MSNs; and (4) our embryonic Sey/Sey mutant analysis shows increased numbers of Emx1lineage MSNs in the striatal primordium. This putative novel source of striatal inhibitory neurons indicates a greater flexibility in telencephalic dorsal-ventral patterning than previously recognized.

In addition to the striatum, the other major target of Emx1-lineage cells is the amygdala. Similar to other telencephalic structures, our work and the work of others have revealed that numerous spatially separate progenitor populations contribute to the developing amygdala (Puelles et al., 2000; Medina et al., 2004; Tole et al., 2005; Hirata et al., 2009). Gene expression and fate-mapping studies have suggested one such population is the cortically derived Emxl lineage, which is expressed in the developing amygdala; analysis of Emx1-Cre mice has revealed recombined cells in the mature amygdala (Fig. 2) (Puelles et al., 2000; Gorski et al., 2002; Medina et al., 2004). Our fate-mapping analysis in this study demonstrates definitively that Emx1-lineage progenitors give

Higher magnification of boxed region in $A$ is shown in $\boldsymbol{B}$. C, $\boldsymbol{D}$, Many GFP ${ }^{+} E m x 1 ; D / x$-lineage cells express TUJ1 (arrowheads), an early neuronal marker, as shown at lower power in Cand high power in $\boldsymbol{D} . \boldsymbol{E}, \boldsymbol{F}$, Low-power $(\boldsymbol{E})$ and high-power $(\boldsymbol{F})$ images of a P30 Emx1-Cre; Dlx5/6-Flpe; RCE: dual brain shows the distribution of intersectional lineage cells (arrowheads) in the striatum. G-I, Optical sections of GFP ${ }^{+}$cells immunolabeled with NeuN (G) or DARPP-32 (I) reveal these Emx1; DIXlineage cells are NeuN ${ }^{+}$and DARPP- $32^{+}(\boldsymbol{G}, \boldsymbol{I})$ but are not positive for the glial lineage marker $\mathrm{Ng} 2(\boldsymbol{H})$. Arrowheads show double-labeled cells for each marker, whereas double arrowheads show non-double-labeled cells. Scale bars: (in $A$ ) $\boldsymbol{A}, 100 \mu \mathrm{m} ; \boldsymbol{B}, \boldsymbol{C}, 50 \mu \mathrm{m}$; (in $\boldsymbol{E}) \boldsymbol{E}, 500 \mu \mathrm{m}$; (in $\boldsymbol{F}) \boldsymbol{F}, 100 \mu \mathrm{m}$. 
rise to excitatory neurons in the amygdala. Our electrophysiological analyses extend the above findings, revealing that these Emx1-lineage cells generate two subclasses of excitatory neurons: pyramidal-like neurons in the lateral nucleus of the amygdala, and burst-firing neurons in the basolateral nucleus of the amygdala.

\section{Differential cell birth date and genetic heterogeneity of Emx1-derived striatal and amygdala neurons}

Our fate-mapping data reveal that Emxl-lineage progenitors generate strikingly disparate neuronal subtypes depending on which structure they will eventually populate. The factors that regulate the decision of Emx1-lineage cells to contribute to one of these specific pools is not known, however, it is likely contingent upon one of three non-mutually-exclusive mechanisms: (1) differential timing of progenitor cell birth, (2) location along the anterior-posterior and/or dorsal-ventral axis of the developing cerebral cortex, or (3) local heterogeneity within the cortical VZ. Our analyses here indicate that both timing and genetic heterogeneity may play a causal role in cell fate decisions within the Emxl lineage in determining their differentiation into striatal inhibitory neurons or amygdala excitatory neurons. The differences in the timing of the generation of Emx1-lineage amygdala neurons versus striatal neurons is quite striking, with Emx1lineage amygdala excitatory neurons generated between E9.5 and E11.5 and Emx1-lineage MSNs generated between E11.5 and E15.5. This early generation of amygdala neurons is consistent with other studies that have indicated that the amygdala is a relatively early-born structure (McConnell and Angevine, 1983; Carney et al., 2006; Hirata et al., 2009; Soma et al., 2009). This differential timing for the generation of neuronal diversity is also highly reminiscent of the mechanisms for the generation of neuronal diversity in numerous regions of the neuraxis including the developing layers of the cerebral cortex, the patch matrix of the striatum, and dorsal-ventral diversity in the spinal cord (Miller and Nowakowski, 1988; Song and Harlan, 1994; Brittis et al., 1995; McConnell, 1995; Lai et al., 2008).

In addition, our gene expression and intersectional fatemapping analyses indicate that genetic heterogeneity of Emx1lineage cells also likely informs cell fate decisions. In support of this, Emx1-lineage cells in the embryonic LGE express Gsx2 and Dlx2, transcription factors required for inhibitory neuronal fate, while Emx1-lineage cells in the developing amygdala primordium exclusively express Pax6, a transcription factor required for pallial fate (Stoykova et al., 1996; Toresson and Campbell, 2001; Yun et al., 2001; Corbin et al., 2003; Stenman et al., 2003; Cobos et al., 2005; Carney et al., 2009). Our Emx1; Dlx intersectional fate mapping provides direct insight into the putative combinatorial code for the differential specification of striatal and amygdala neurons, as the subpopulation of Emx1-lineage neurons in the striatum appear to require $D l x$ expression to become inhibitory neurons. This is consistent with previous work using Emxl and Dlx genetic fate mapping to analyze the origins of $\mathrm{TH}^{+}$and $\mathrm{CR}^{+}$ interneurons olfactory bulb neurons, which in part appear to be generated from the ventral pallium and the LGE (Kohwi et al., 2007; Batista-Brito et al., 2008), regions in which overlap between Emx1 and Dlx lineages occurs (Kohwi et al., 2007). Consistent with our findings, previous work has indicated that $D l x$ genes are necessary for the initiation of GABA production, and so it may be that Emx1-lineage cells must also express Dlx family members to become specified to an inhibitory neuronal phenotype (Stühmer et al., 2002; Cobos et al., 2005).
Although our data are strongly suggestive that both timing and genetic heterogeneity are key determinants in the differential fate of striatal versus amygdala Emx1-lineage neurons, the exact mechanisms of this determination are unclear. It is possible that Emx1-lineage neurons in the developing cerebral cortex (or LGE) upregulate $D l x$ genes (and other genes that specify the ventral program) before they become postmitotic and migrate to the striatum. In support of this, previous analyses have revealed that a subpopulation of cortical progenitors express Dlx2 in the ventricular zone (Nery et al., 2003), and our in vitro differentiation assays shown here reveal that $E m x 1^{+}$cortical progenitors have the capacity to generate MSNs. Alternatively, the differential fates of ventrally migrating Emx1-lineage cells whose ultimate destination is the striatum or amygdala may also be influenced by external cues at the boundary between the developing cortex and striatum (the PSB). This area expresses a number of molecules that are secreted locally, including $S f r p 2$ and $T g f \alpha$, and the more caudally expressed Fgf7 (Stoykova et al., 1996; Toresson and Campbell, 2001; Carney et al., 2009). As Emx1-lineage cells from the pallium migrate ventrally through the region at the PSB, and more caudally, at the level of the developing amygdala, it is possible that these migrating $E m \times 1^{+}$cells upregulate different transcription factors that endow them with the capacity to migrate to different locations and differentiate into different cell subtypes when compared with $E m x 1^{+}$cells that remain in the cerebral cortex. Indeed, our observed increase in the numbers of Emx1derived neurons in the LGE in Sey/Sey mice, which display a disrupted PSB, is consistent with such a role for the PSB in fate and/or migratory route determination.

\section{References}

Ade KK, Janssen MJ, Ortinski PI, Vicini S (2008) Differential tonic GABA conductances in striatal medium spiny neurons. J Neurosci 28:11851197.

Alcántara S, Ruiz M, D’Arcangelo G, Ezan F, de Lecea L, Curran T, Sotelo C, Soriano E (1998) Regional and cellular patterns of reelin mRNA expression in the forebrain of the developing and adult mouse. J Neurosci 18:7779-7799.

Arlotta P, Molyneaux BJ, Jabaudon D, Yoshida Y, Macklis JD (2008) Ctip2 controls the differentiation of medium spiny neurons and the establishment of the cellular architecture of the striatum. J Neurosci 28:622-632.

Bai J, Ramos RL, Paramasivam M, Siddiqi F, Ackman JB, LoTurco JJ (2008) The role of DCX and LIS1 in migration through the lateral cortical stream of developing forebrain. Dev Neurosci 30:144-156.

Batista-Brito R, Close J, Machold R, Fishell G (2008) The distinct temporal origins of olfactory bulb interneuron subtypes. J Neurosci 28:3966-3975.

Brittis PA, Meiri K, Dent E, Silver J (1995) The earliest patterns of neuronal differentiation and migration in the mammalian central nervous system. Exp Neurol 134:1-12.

Carić D, Gooday D, Hill RE, McConnell SK, Price DJ (1997) Determination of the migratory capacity of embryonic cortical cells lacking the transcription factor Pax-6. Development 124:5087-5096.

Carney RS, Alfonso TB, Cohen D, Dai H, Nery S, Stoica B, Slotkin J, Bregman BS, Fishell G, Corbin JG (2006) Cell migration along the lateral cortical stream to the developing basal telencephalic limbic system. J Neurosci 26:11562-11574.

Carney RS, Cocas LA, Hirata T, Mansfield K, Corbin JG (2009) Differential regulation of telencephalic pallial-subpallial boundary patterning by Pax6 and Gsx2. Cereb Cortex 19:745-759.

Chapouton P, Gärtner A, Götz M (1999) The role of Pax6 in restricting cell migration between developing cortex and basal ganglia. Development 126:5569-5579.

Cobos I, Calcagnotto ME, Vilaythong AJ, Thwin MT, Noebels JL, Baraban SC, Rubenstein JL (2005) Mice lacking Dlxl show subtype-specific loss of interneurons, reduced inhibition and epilepsy. Nat Neurosci 8:10591068.

Corbin JG, Rutlin M, Gaiano N, Fishell G (2003) Combinatorial function of 
the homeodomain proteins $\mathrm{Nkx} 2.1$ and Gsx2 in ventral telencephalic patterning. Development 130:4895-4906.

Costa MR, Wen G, Lepier A, Schroeder T, Götz M (2008) Par-complex proteins promote proliferative progenitor divisions in the developing mouse cerebral cortex. Development 135:11-22.

Donoghue JP, Herkenham M (1986) Neostriatal projections from individual cortical fields conform to histochemically distinct striatal compartments in the rat. Brain Res 365:397-403.

Fishell G, van der Kooy D (1987) Pattern formation in the striatum: developmental changes in the distribution of striatonigral neurons. J Neurosci 7:1969-1978

Fishell G, van der Kooy D (1991) Pattern formation in the striatum: neurons with early projections to the substantia nigra survive the cell death period. J Comp Neurol 312:33-42.

Fishell G, Rossant J, van der Kooy D (1990) Neuronal lineages in chimeric mouse forebrain are segregated between compartments and in the rostrocaudal and radial planes. Dev Biol 141:70-83.

Fogarty M, Grist M, Gelman D, Marín O, Pachnis V, Kessaris N (2007) Spatial genetic patterning of the embryonic neuroepithelium generates GABAergic interneuron diversity in the adult cortex. J Neurosci 27: 10935-10946.

Gal JS, Morozov YM, Ayoub AE, Chatterjee M, Rakic P, Haydar TF (2006) Molecular and morphological heterogeneity of neural precursors in the mouse neocortical proliferative zones. J Neurosci 26:1045-1056.

Gerfen CR (1984) The neostriatal mosaic: compartmentalization of corticostriatal input and striatonigral output systems. Nature 311:461-464.

Gerfen CR (1985) The neostriatal mosaic. I. Compartmental organization of projections from the striatum to the substantia nigra in the rat. J Comp Neurol 236:454-476.

Gerfen CR (1992) The neostriatal mosaic: multiple levels of compartmental organization. Trends Neurosci 15:133-139.

Gerfen CR, Engber TM, Mahan LC, Susel Z, Chase TN, Monsma FJ Jr, Sibley DR (1990) D1 and D2 dopamine receptor-regulated gene expression of striatonigral and striatopallidal neurons. Science 250:1429-1432.

Gerfen CR, Paletzki R, Worley P (2008) Differences between dorsal and ventral striatum in Drdla dopamine receptor coupling of dopamine- and cAMP-regulated phosphoprotein-32 to activation of extracellular signalregulated kinase. J Neurosci 28:7113-7120.

Gorski JA, Talley T, Qiu M, Puelles L, Rubenstein JL, Jones KR (2002) Cortical excitatory neurons and glia, but not GABAergic neurons, are produced in the Emx1-expressing lineage. J Neurosci 22:6309-6314.

Hefner K, Whittle N, Juhasz J, Norcross M, Karlsson RM, Saksida LM, Bussey TJ, Singewald N, Holmes A (2008) Impaired fear extinction learning and cortico-amygdala circuit abnormalities in a common genetic mouse strain. J Neurosci 28:8074-8085.

Hill RE, Favor J, Hogan BL, Ton CC, Saunders GF, Hanson IM, Prosser J, Jordan T, Hastie ND, van Heyningen V (1991) Mouse small eye results from mutations in a paired-like homeobox-containing gene. Nature 354:522-525.

Hirata T, Li P, Lanuza GM, Cocas LA, Huntsman MM, Corbin JG (2009) Identification of distinct telencephalic progenitor pools for neuronal diversity in the amygdala. Nat Neurosci 12:141-149.

Kim JC, Dymecki SM (2009) Genetic fate-mapping approaches: new means to explore the embryonic origins of the cochlear nucleus. Methods Mol Biol 493:65-85.

Kohwi M, Petryniak MA, Long JE, Ekker M, Obata K, Yanagawa Y, Rubenstein JL, Alvarez-Buylla A (2007) A subpopulation of olfactory bulb GABAergic interneurons is derived from Emx1- and Dlx5/6-expressing progenitors. J Neurosci 27:6878-6891.

Krushel LA, Johnston JG, Fishell G, Tibshirani R, van der Kooy D (1993) Spatially localized neuronal cell lineages in the developing mammalian forebrain. Neuroscience 53:1035-1047.

Krushel LA, Fishell G, van der Kooy D (1995) Pattern formation in the mammalian forebrain: striatal patch and matrix neurons intermix prior to compartment formation. Eur J Neurosci 7:1210-1219.

Lai T, Jabaudon D, Molyneaux BJ, Azim E, Arlotta P, Menezes JR, Macklis JD (2008) SOX5 controls the sequential generation of distinct corticofugal neuron subtypes. Neuron 57:232-247.

Likhtik E, Popa D, Apergis-Schoute J, Fidacaro GA, Paré D (2008) Amygdala intercalated neurons are required for expression of fear extinction. Nature 454:642-645.
Maren S, Quirk GJ (2004) Neuronal signalling of fear memory. Nat Rev Neurosci 5:844-852.

Marin O, Anderson SA, Rubenstein JL (2000) Origin and molecular specification of striatal interneurons. J Neurosci 20:6063-6076.

Marowsky A, Yanagawa Y, Obata K, Vogt KE (2005) A specialized subclass of interneurons mediates dopaminergic facilitation of amygdala function. Neuron 48:1025-1037.

Mason HA, Rakowiecki SM, Raftopoulou M, Nery S, Huang Y, Gridley T, Fishell G (2005) Notch signaling coordinates the patterning of striatal compartments. Development 132:4247-4258.

McConnell J, Angevine JB Jr (1983) Time of neuron origin in the amygdaloid complex of the mouse. Brain Res 272:150-156.

McConnell SK (1995) Strategies for the generation of neuronal diversity in the developing central nervous system. J Neurosci 15:6987-6998.

Medina L, Legaz I, González G, De Castro F, Rubenstein JL, Puelles L (2004) Expression of Dbx1, Neurogenin 2, Semaphorin 5A, Cadherin 8, and Emx1 distinguish ventral and lateral pallial histogenetic divisions in the developing mouse claustroamygdaloid complex. J Comp Neurol 474:504523.

Miller MW, Nowakowski RS (1988) Use of bromodeoxyuridine-immunohistochemistry to examine the proliferation, migration and time of origin of cells in the central nervous system. Brain Res 457:44-52.

Nery S, Fishell G, Corbin JG (2002) The caudal ganglionic eminence is a source of distinct cortical and subcortical cell populations. Nat Neurosci 5:1279-1287.

Nery S, Corbin JG, Fishell G (2003) Dlx2 progenitor migration in wild type and Nkx2.1 mutant telencephalon. Cereb Cortex 13:895-903.

Novak A, Guo C, Yang W, Nagy A, Lobe CG (2000) Z/EG, a double reporter mouse line that expresses enhanced green fluorescent protein upon Cremediated excision. Genesis 28:147-155.

Olsson M, Bentlage C, Wictorin K, Campbell K, Björklund A (1997) Extensive migration and target innervation by striatal precursors after grafting into the neonatal striatum. Neuroscience 79:57-78.

Puelles L, Kuwana E, Puelles E, Bulfone A, Shimamura K, Keleher J, Smiga S, Rubenstein JL (2000) Pallial and subpallial derivatives in the embryonic chick and mouse telencephalon, traced by the expression of the genes Dlx-2, Emx-1, Nkx-2.1, Pax-6, and Tbr-1. J Comp Neurol 424:409-438.

Quinn JC, Molinek M, Martynoga BS, Zaki PA, Faedo A, Bulfone A, Hevner RF, West JD, Price DJ (2007) Pax6 controls cerebral cortical cell number by regulating exit from the cell cycle and specifies cortical cell identity by a cell autonomous mechanism. Dev Biol 302:50-65.

Ragsdale CW Jr, Graybiel AM (1988) Fibers from the basolateral nucleus of the amygdala selectively innervate striosomes in the caudate nucleus of the cat. J Comp Neurol 269:506-522.

Remedios R, Huilgol D, Saha B, Hari P, Bhatnagar L, Kowalczyk T, Hevner RF, Suda Y, Aizawa S, Ohshima T, Stoykova A, Tole S (2007) A stream of cells migrating from the caudal telencephalon reveals a link between the amygdala and neocortex. Nat Neurosci 10:1141-1150.

Sah P, Faber ES, Lopez De Armentia M, Power J (2003) The amygdaloid complex: anatomy and physiology. Physiol Rev 83:803-834.

Schmahl W, Knoedlseder M, Favor J, Davidson D (1993) Defects of neuronal migration and the pathogenesis of cortical malformations are associated with Small eye (Sey) in the mouse, a point mutation at the Pax-6-locus. Acta Neuropathol 86:126-135.

Soma M, Aizawa H, Ito Y, Maekawa M, Osumi N, Nakahira E, Okamoto H, Tanaka K, Yuasa S (2009) Development of the mouse amygdala as revealed by enhanced green fluorescent protein gene transfer by means of in utero electroporation. J Comp Neurol 513:113-128.

Song DD, Harlan RE (1994) Genesis and migration patterns of neurons forming the patch and matrix compartments of the rat striatum. Brain Res Dev Brain Res 83:233-245.

Sousa VH, Miyoshi G, Hjerling-Leffler J, Karayannis T, Fishell G (2009) Characterization of Nkx6-2-derived neocortical interneuron lineages. Cereb Cortex 19 [Suppl 1]:i1-i10.

Srinivas S, Watanabe T, Lin CS, William CM, Tanabe Y, Jessell TM, Costantini F (2001) Cre reporter strains produced by targeted insertion of EYFP and ECFP into the ROSA26 locus. BMC Dev Biol 1:4.

Stenman J, Toresson H, Campbell K (2003) Identification of two distinct progenitor populations in the lateral ganglionic eminence: implications for striatal and olfactory bulb neurogenesis. J Neurosci 23:167174. 
Stoykova A, Fritsch R, Walther C, Gruss P (1996) Forebrain patterning defects in Small eye mutant mice. Development 122:3453-3465.

Stühmer T, Anderson SA, Ekker M, Rubenstein JL (2002) Ectopic expression of the Dlx genes induces glutamic acid decarboxylase and Dlx expression. Development 129:245-252.

Swanson LW, Petrovich GD (1998) What is the amygdala? Trends Neurosci 21:323-331.

Tang X, Falls DL, Li X, Lane T, Luskin MB (2007) Antigen-retrieval procedure for bromodeoxyuridine immunolabeling with concurrent labeling of nuclear DNA and antigens damaged by $\mathrm{HCl}$ pretreatment. J Neurosci 27:5837-5844.

Tole S, Remedios R, Saha B, Stoykova A (2005) Selective requirement of Pax6, but not Emx2, in the specification and development of several nuclei of the amygdaloid complex. J Neurosci 25:2753-2760.

Toresson H, Campbell K (2001) A role for Gsh1 in the developing striatum and olfactory bulb of Gsx2 mutant mice. Development 128:4769-4780.

Waclaw RR, Wang B, Pei Z, Ehrman LA, Campbell K (2009) Distinct temporal requirements for the homeobox gene gsx 2 in specifying striatal and olfactory bulb neuronal fates. Neuron 63:451-465.

Warren N, Caric D, Pratt T, Clausen JA, Asavaritikrai P, Mason JO, Hill RE, Price DJ (1999) The transcription factor, Pax6, is required for cell proliferation and differentiation in the developing cerebral cortex. Cereb Cortex 9:627-635.
Wichterle H, Garcia-Verdugo JM, Herrera DG, Alvarez-Buylla A (1999) Young neurons from medial ganglionic eminence disperse in adult and embryonic brain. Nat Neurosci 2:461-466.

Wichterle H, Turnbull DH, Nery S, Fishell G, Alvarez-Buylla A (2001) In utero fate mapping reveals distinct migratory pathways and fates of neurons born in the mammalian basal forebrain. Development 128:3759-3771.

Willaime-Morawek S, Seaberg RM, Batista C, Labbé E, Attisano L, Gorski JA, Jones KR, Kam A, Morshead CM, van der Kooy D (2006) Embryonic cortical neural stem cells migrate ventrally and persist as postnatal striatal stem cells. J Cell Biol 175:159-168.

Willaime-Morawek S, van der Kooy D (2008) Cortex-and striatum-derived neural stem cells produce distinct progeny in the olfactory bulb and striatum. Eur J Neurosci 27:2354-2362.

Yoshida M, Suda Y, Matsuo I, Miyamoto N, Takeda N, Kuratani S, Aizawa S (1997) Emx1 and Emx2 functions in development of dorsal telencephalon. Development 124:101-111.

Young KM, Fogarty M, Kessaris N, Richardson WD (2007) Subventricular zone stem cells are heterogeneous with respect to their embryonic origins and neurogenic fates in the adult olfactory bulb. J Neurosci 27:8286-8296.

Yun K, Potter S, Rubenstein JL (2001) Gsx2 and Pax6 play complementary roles in dorsoventral patterning of the mammalian telencephalon. Development 128:193-205. 